\title{
Does doing good lead to doing better in emerging markets? Stock market responses to the SRI index announcements in Brazil, China, and South Africa
}

\author{
Peng Zou ${ }^{1} \cdot$ Qi Wang ${ }^{2,3}$ (D) Jinhong Xie ${ }^{4} \cdot$ Chenxi Zhou $^{5}$
}

Received: 29 August 2018 / Accepted: 1 April 2019 / Published online: 22 April 2019

(C) The Author(s) 2019

\begin{abstract}
This paper investigates whether and how emerging markets reward firms' corporate social responsibility (CSR) performance. We focus on the socially responsible investment (SRI) index, which lists the top CSR performers and serves as a tool to help investors make investment decisions based on financial and social criteria. We empirically test the financial market responses to the announcements of pioneering SRI indices recently launched in Brazil, China, and South Africa. We find that inclusion on an SRI index in these markets is associated with positive abnormal returns. However, inclusion on an SRI index does not benefit all firms equally: the positive financial response is strengthened by R\&D expenditures but weakened by advertising expenditures; it is stronger for firms that have expanded globally to developing countries than those to developed countries.
\end{abstract}

Keywords Emerging markets $\cdot$ Corporate social responsibility $\cdot$ Socially responsible investment index $\cdot$ Event study

\section{Introduction}

Corporate social responsibility (CSR) has drawn increasing attention from marketing scholars in recent years. One important issue regarding the impact of CSR is whether and how firms' CSR activities affect their financial performance. While many studies have investigated the CSR-finance relationship and offered valuable insights (e.g., Lenz et al. 2017; Mishra and Modi 2016; Servaes and Tamayo 2013; Peloza and Shang 2011; Luo and Bhattacharya 2006, 2009), most of them have been conducted in developed economies, in which CSR is considered standard practice.

Rajendra Srivastava and V. Kumar served as Special Issue Guest Editors for this article.

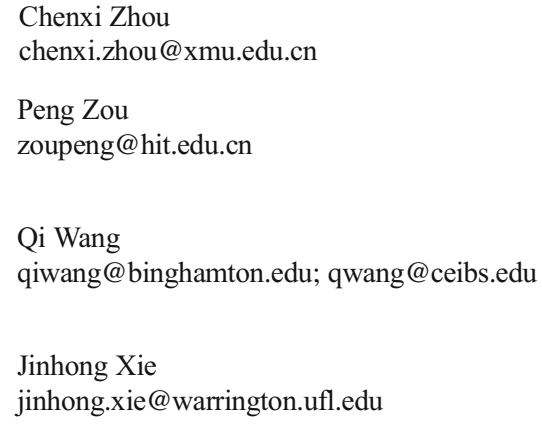

Although formal CSR practices remain less prevalent in emerging markets, these practices have grown rapidly in the last decade. Consider the number of companies that have registered and reported their CSR activities on the Global Reporting Initiatives (GRI), an indicator widely recognized for gauging company involvement in CSR. The number of CSR reports made by companies based in emerging markets increased by 57\% from 2012 to 2017, on a year-over-year basis. In particular, the number of CSR reports made by Chinese companies has risen $170.6 \%$ from 2012 to 2017 (GRI, 2012-2017).

These recent developments call for more academic attention to CSR in emerging markets, which may differ from

1 Department of Marketing, School of Management, Harbin Institute of Technology, 13 Fayuan Street, Nangang District, Harbin 150001, China

2 State University of New York at Binghamton, Binghamton, NY 13902, USA

3 China Europe International Business School, 699 Hongfeng Road, Shanghai 201206, China

4 Warrington College of Business Administration, University of Florida, P.O. Box 117155, Gainesville, FL 32611-7155, USA

5 School of Management, Xiamen University, $361005 \mathrm{Fu}$ Jian, People's Republic of China 
developed markets in many factors crucial to CSR practices and effectiveness - e.g., awareness of the CSR concept, economic development, legal and regulatory systems, business standards, and information transparency, among others. While several recent studies have taken the initiatives to understand the CSR-finance relationship in emerging markets, they have used various CSR measures that are either based on a specific aspect of CSR or developed by companies/scholars themselves. For example, Arya and Zhang (2009) based their study on the BusinessMap Foundation BEE Database, developed by South Africa's government to record a specific aspect of CSR - black economic empowerment activities. Mishra and Suar (2010) developed a perceptual measure of CSR based on their survey, and Wang and $\mathrm{Li}$ (2016) used the CSR reports released by companies themselves. To advance our understanding about CSR-finance relationship in emerging markets, clearly, more studies are needed to use CSR measures that are more comprehensive and objective.

This paper investigates the effectiveness of CSR in emerging markets with special attention to the impact of the socially responsible investment (SRI) index on firms' financial value. Socially responsible investment, also known as sustainable and responsible investment, has become a widely accepted investment approach in recent years in the developed world. Using this approach, investors base their investment decisions not only on financial criteria but also on ethical criteria such as social and environmental impact (Sparkes 2001). Since 1990, a number of indices have been launched in developed countries to facilitate SRI such as the Domini 400 Social Index (DSI), the Dow Jones Sustainability Index (DJSI) in the U.S., the FTSE4Good in the U.K., the Jantzi Social Index in Canada, the Humanix 50 in Sweden, and the WestpacMonash Eco Index in Australia. In 2016, 21.6\% of stock purchases by individual and institutional investments were made in part by using socially responsible selection in the U.S., ${ }^{1}$ and SRI-driven investment decisions in European stock markets reached $\$ 12.04$ trillion. $^{2}$

The common use of SRI indice in developed economies has motivated many scholars to investigate their financial markets responses in these markets. For example, the literature has examined the stock market responses to the SRI indices in the U.S. (i.e., Domini 400 Social Index), in Europe (i.e., FTSE4Good UK 50 Index and DJ STOXX 600 Index), and in Japan (i.e., Morningstar) (e.g., Sauer 1997; Statman 2000; McWilliams and Siegel 2000; Ramchander et al. 2012; Curran and Moran 2007; Clacher and Hagendorff 2012; Russo and Mariani 2013; Oberndorfer et al. 2013; Nakai et al. 2013).

In comparison, SRI practices are relatively new to emerging countries. To our knowledge, only three emerging

\footnotetext{
1 The Trend Report of the Social Investment Forum in 2016.

2 European SRI Study, 2016. http://www.eurosif.org/wp-content/uploads/ 2016/11/SRI-study-2016-HR.pdf.
}

countries (South Africa, Brazil, and China) have launched domestic SRI indices. ${ }^{3}$ While these newly launched SRI indices by stock exchanges in emerging markets are specifically designed to guide emerging-market investors for their social investments, it is unclear if and how such information affects investors' investment decisions.

This paper examines the stock market responses to the release of an SRI index in emerging markets. We ask and answer three research questions regarding the CSR-finance relationship in such markets: (1) Do investors respond to an SRI index release? (2) Do the benefits of inclusion in an SRI index, if any, vary for firms with their globalization activities, especially the direction of its global market expansion (i.e., to developed vs. developing countries)? (3) How do firms' marketing expenditures in advertising and R\&D moderate investors' response to the announcement of an SRI index?

These are important questions to CSR practitioners and scholars. First, based on data from the developed economies, extant studies have found that (1) investors do not respond to an SRI announcement in the early years when the index is first launched, but positively respond to such an announcement event after the index has been established for several years (e.g., Sauer 1997; Statman 2000; Curran and Moran 2007; Ramchander et al. 2012; Nakai et al. 2013; Clacher and Hagendorff 2012), and (2) investors do not respond to a less-known SRI index (such as the Dow Jones STOXX Sustainability Index) but positively respond to a well-known SRI index (such as the Dow Jones Sustainability World Index) (Oberndorfer et al. 2013). These findings suggest that, in general, investors respond to an SRI index only after it has gained sufficient popularity. Since domestic SRI indices in emerging markets are relatively new and unknown, one might question if the stock markets respond to such an index, particularly when it is first launched.

Second, as emerging-market firms have experienced rapid expansion to the global playfield (e.g., engaged in crossborder mergers and acquisitions) in recent decades (Zhou et al. 2016), they may adapt to global markets with various levels of CSR standards. As a result, global expansion activities may moderate the relationship between the release of an SRI index and stock market responses in emerging markets. In particular, we are interested in the potential different moderating effects for firms that have expanded globally to a developed or developing country.

Third, while the marketing literature has suggested that firms' marketing expenditures moderate the relationship between firms' CSR investment and their financial performance in developed economies (e.g., Hull and Rothenberg 2008; Luo

\footnotetext{
${ }^{3}$ Although a handful of global SRI indices are available to global investors (e.g., MSCI Global Socially Indexes, S\&P ESG India, Dow Jones Sustainability Korea Index), domestic SRI indices are still limited in many emerging markets.
} 
and Bhattacharya 2006; Servaes and Tamayo 2013), it is less clear if such moderating effects identified in developed markets remains the same in emerging markets. Specifically, it is unknown if and how marketing expenditures in advertising and $\mathrm{R} \& \mathrm{D}$ moderate the stock market responses to the announcement of an SRI index. Given that emerging-market investors may differ from those in developed markets (e.g., lack of trust and investment experience), we may expect different moderating effects of marketing in emerging markets.

To answers these questions, we conduct an event study to examine whether and how a firm's inclusion in the SRI indices in the three emerging markets affects the firm's stock prices at the time of their initial announcements (i.e., their first index release). These indices include (1) the SSE Social Responsibility Index (launched by the Shanghai Stock Exchange on August 5, 2009), (2) the SZSE CSR Index (launched by the Shenzhen Stock Exchange on August 3, 2009), (3) the Johannesburg Stock Exchange SRI Index (launched on May 19th, 2004), and (4) the Brazilian Corporate Sustainability Index (launched on December 1, 2005). Based on firms' CSR performance scores, each of the two Chinese SRI indices is composed of the top 100 public Chinese firms, whereas the Brazilian SRI index listed 40 Brazilian firms and the South Africa SRI index listed 51 South African firms in their respective indices.

Our empirical analysis reveals some interesting findings. First, our results show that inclusion in these SRI indices is associated with positive abnormal returns on the day when these indices were first released, which is different from existing studies that have found no positive response to an SRI index at its first release in developed economies. This finding suggests that although emerging markets are in the early stages of developing CSR, investors are aware of these SRI indices, and an outstanding performance on CSR (such as being listed in the SRI index) indeed creates financial benefits for listed companies. More importantly, we find that a positive response to an SRI index holds across countries (based on data of the three emerging markets) and across time (based on data of eight-year subsequent releases of two Chinese SRI indices).

Furthermore, we find that the benefit of inclusion in an SRI index is higher for firms that have expanded globally to developing markets than those that have expanded to developed markets. More strikingly, we find that the two marketing investments - R\&D and advertising — play different roles with respect to the benefit of inclusion in an SRI index. The financial value of being included in an SRI index is weakened by advertising expenditures but strengthened by R\&D expenditures. The former result is particularly interesting since past research based on data of CSR activities (instead of an SRI index) in developed countries has suggested that advertising strengthens the impact of CSR (Servaes and Tamayo 2013), while our research, based on data of an SRI index in emerging markets, shows the opposite. Note that a firm's high advertising expenditures can increase consumer awareness, which can lead to stronger investor responses when the firm is included in SRI indices. However, high advertising expenditures can also create consumer skepticism of a firm's CSR motivation, since advertising is deemed to be driven by self-interest (i.e., to increase profits), whereas CSR activities are supposed to be driven by social concerns. Such a negative moderating effect of advertising in emerging markets is likely driven by a lack of regulations in these markets-i.e., advertisers will not be held accountable for faulty claims or deceptive advertising.

This study contributes to both the CSR literature and marketing literature. To demonstrate our research contributions, we summarized relevant literature regarding three key issues of CSR and briefly state our incremental contributions in Table 1 . First, our research brings attention of an SRI index, a relatively comprehensive and objective CSR measure, to the research regarding the CSR-finance relationship in emerging markets (see key issue I in Table 1). This extension not only offers us an opportunity to investigate the impact of newly launched SRI indices in emerging markets, but also allows us to develop new insights on how the impact of an SRI index in emerging markets may differ from that in developed economies.

Second, our research makes contributions to the literature regarding the stock market responses to the announcement of SRI index (see key issue II in Table 1). We extend to emerging markets the existing research, which has previously focused on developed markets (e.g., Sauer 1997; Statman 2000; Curran and Moran 2007; Ramchander et al. 2012; Clacher and Hagendorff 2012; Nakai et al. 2013; Oberndorfer et al. 2013). Since the SRI index is a relatively new concept to emerging markets, understanding its financial impact is of significance to both CSR scholars and practitioners. The positive responses to the release of an SRI index discovered in this study underscore the effectiveness of SRI indices offered by domestic stock exchanges on guiding emerging-market investors for their social investments. It is particularly interesting that the impact of SRI in emerging economies indeed differs from that in development economies, as revealed in our study. Specifically, existing studies based on data from developed countries have identified a common pattern: investors positively respond to an SRI index release only if the index has gained sufficient popularity (i.e., only after several years when the index has proven to be established and only for those well-known SRI indices). Based on data from emerging countries, however, our empirical analysis reveals a different pattern: investors responded positively to an SRI index even at the time when it was launched (i.e., the first release). Such positive responses to an SRI index hold across all three emerging countries we studied, China, Brazil, and South Africa.

Third, our study also contributes to the literature regarding the stock market responses to an SRI index by identifying possible moderators (see key issue III in Table 1). Extant studies, though differ in the specific SRI index or countries examined, 
Table 1 Relevant literature and our incremental contribution
Key Issue and Main Finding
Publications
Our Incremental Contribution

(I) Impact of CSR on Firms Financial Performance in Emerging Markets

Key issue: whether and how do firms' CSR activities affect their financial performance in emerging markets?

Main findings: $\quad$ Arya and Zhang (2009);

- The stock market responses to firms' CSR initiatives Cheung, Tan, Ahn and Zhang (2010); differ for early and late adopters.

- A positive relationship exists between CSR practices and financial performance in emerging markets in long run.

- The strength of such a positive relationship depends on the quality of firms' CSR reporting, if they are publicly traded, and the development stage of stock markets.

(II) Stock Market Response to an SRI index

Key issue: whether and how do stock markets respond to the SRI Index?

Main findings

Based on data from developed countries:

- No significantly positive returns are found to the announcement of an SRI index in the first year when it is launched.

- Positive returns are found significant only a few years after the launch of the SRI index and only for well-known SRI indices.

The existing studies have not examined this issue in emerging markets and have not considered marketing variables as potential moderators.
Cheung, Tan, Ahn and Zhang (2010);
Mishra and Suar (2010);

Su et al. (2016); Wang and Li (2016)
Sauer (1997); Statman (2000); Curran and Moran (2007); Nakai et al. (2013); Ramchander et al. (2012); Clacher and Hagendorff (2012); Oberndorfer et al. (2013)
- Our study draws attention to the SRI index, a comprehensive and objective measure of CSR performance launched by stock exchanges in emerging markets, rather than the CSR measures developed either based on a specific area of CSR or by the authors

- We extend the research of the stock market response to the SRI indices to emerging markets. Our results show that, different from the research based on developed markets, stock markets responded positively to the first SRI index developed in each of three emerging markets (China, Brazil, and South Africa) when these index were first launched (i.e., the first year).

- We introduce three marketing moderators to the research on the effectiveness of an SRI index. Our results show that: firms benefit more from being included in an SRI index if they have expanded globally to emerging markets than to developed markets, and if they have spent large expenditures in R\&D but less in advertising.

(III) Moderating Roles of Marketing in the CSR-Finance Relationship

Key issue: whether and how do marketing expenditures in advertising and $\mathrm{R} \& \mathrm{D}$ moderate the effectiveness of CSR?

Main findings:

Based on data from developed countries:

- The CSR-finance relationship is positively moderated by advertising expenditures.

- The CSR-finance relationship can be either positively or negatively moderated by $R \& D$ expenditures.

Globalization activity has not been considered as a potential moderator for the CSR-finance relationship.

Luo and Bhattacharya (2006); Hull and Rothenberg (2008); Servaes and Tamayo (2013)
- Different from the studies conducted in developed countries, we find that the CSR-finance relationship is negatively moderated by advertising expenditure in emerging markets.

- We identify globalization as a new marketing moderator on the CSR-finance relationship and find that the benefit of being included in SRI index is higher for firms engaged in market expansion to developing countries than those to developed countries. have focused on the main effect of an SRI index (Curran and Moran 2007; Clacher and Hagendorff 2012; Menz 2010; Nakai et al. 2013; Oberndorfer et al. 2013; Russo and Mariani 2013). Our study goes one step further to identify factors that may moderate the investors' response to an SRI index. Specifically, we identified two sets of moderators, (1) globalization and (2) marketing expenditure. Our results demonstrate that the benefits from being included in an SRI index in emerging markets vary with the globalization directions (i.e., expanded to developing or developed countries) and depend on firms' marketing expenditures in R\&D and advertising.

In the next section, we provide an overview of SRI index research and develop our hypotheses concerning the stock market response to an SRI index in emerging countries. We then describe our data and estimation method and present our empirical findings. Finally, we conclude with a summary, 
discussion of managerial and policy implications, and suggestions for further research.

\section{Theoretical background and hypothesis development}

\section{Socially responsible investment (SRI)}

As socially responsible investment (SRI) has become an increasingly popular practice for investors in developed economies, a growing number of studies have investigated the financial performance of SRI indices based on these markets. For example, some studies have examined the financial performance of firms listed in the Domini 400 Social Index (DSI) in the U.S. (e.g., Sauer 1997; Statman 2000; McWilliams and Siegel 2000; Ramchander et al. 2012); others have investigated financial performance based on SRI indices such as the FTSE4Good UK 50 Index (Curran and Moran 2007; Clacher and Hagendorff 2012; Russo and Mariani 2013), the DJ STOXX 600 Index in Europe (Oberndorfer et.al. 2013), SAM's selection of socially responsible bonds in Zurich (Menz 2010), and Morningstar in Japan (Nakai et al. 2013).

In general, these studies have not found significantly higher returns of inclusion in an SRI index, compared to nonrestrictive investment in the early years after the SRI index was first announced (e.g., Sauer 1997; Statman 2000; Curran and Moran 2007; Nakai et al. 2013). Positive returns were found to be significant only quite a few years after the launch of the index (e.g., from the inception of the Domini 400 Social Index in 1990 to 2007 in Ramchander et al. 2012; from the inception of the FTSE4Good UK 50 Index in July 2001 to March 2008 in Clacher and Hagendorff 2012), and only for well-known SRI indices. For example, when Oberndorfer et al. (2013) compared the effect of German corporations' inclusion in a newly launched SRI index (the Dow Jones STOXX Sustainability Index, launched in 2001) with that of a well-known SRI index (the Dow Jones Sustainability World Index, launched in 1999), they found that abnormal returns were significantly positive for those firms included in the well-known index, but insignificant for those in the newly launched SRI index between 1999 to 2002.

As suggested in these studies, investors are either unaware of the existence of SRI indices or do not fully understand how these listed firms perform when an SRI index is new to them (Oberndorfer et al. 2013; Nakai et al. 2013). Investors are concerned about whether they can gain any significantly higher returns by using social criteria to limit their investment universe, as doing so may result in increased volatility, reduced diversification, additional costs of screening and monitoring, and thus lower returns (Sauer 1997).
Financial performance of SRIs in emerging markets

Intuitively, one could expect that investors in emerging markets may not respond to the launch of an SRI index, a result found in past literature, because the concept is also new to emerging-market investors. However, since emerging markets represent a transitional economic development stage that differs from developed economies profoundly, the announcement of an SRI index may create positive abnormal returns to firms included in the index when the index is first released in emerging markets.

Specifically, we suggest that investors in emerging markets differ from their counterparts in developed markets in three aspects: (1) the level of uncertainties involved in their investment selection of CSR firms, (2) the incentive to apply CSR criteria in their investment selection, and (3) the level of investment experience in stock markets. These fundamental differences increases the awareness and the strength of the announcement of an SRI index and in turn lead to strong signaling effects on emerging-market investors.

First, investors in emerging markets face a much higher level of information asymmetry and uncertainties in their selection of CSR firms. This is due to a lack of strong regulation and sufficient information disclosure of firms' CSR engagement in emerging markets. For example, because of weak regulations in emerging markets, it is unclear to many emerging-market firms what social responsibility exactly constitutes, how they should regularly report their CSR activities (i.e., which measurements and evaluations), and how they are regulated with regard to unlawful conduct (e.g., Krishna 1992; CSM 2001; Mishra and Suar 2010). Even if firms issue CSR reports, different firms focus on different aspects of CSR, which makes it challenging for investors to compare and evaluate which firms are the top CSR performers. Furthermore, compared to developed markets, where many organizations provide comprehensive and publically available data sources for investors to retrieve firms' CSR reports, it is still difficult for emerging-market investors to find such information sources and compare them across different firms. As $C N B C$ noticed, it is difficult to implement socially responsible investment in emerging markets, as only a handful of funds are now available to investors who want to follow these criteria and invest in developing market economics (CNBC.com, December 30, 2013).

In regard to evaluating the financial performance of CSR firms, there is also an information problem for investors in emerging markets. As the Wall Street Journal reported, financial disclosure in emerging markets tends not to be as reliable as in developed markets, which makes it difficult to discern which companies are socially responsible (WSJ, Jan. 11, 2011). Such an information problem is accentuated due to weak CSR regulation in these markets, which further intensifies the information asymmetry between investors and CSR firms in emerging markets. 
Second, investors in emerging markets have a stronger incentive to apply social criteria in their investments. With rapid economic development in past decades, many emerging markets are experiencing growing environmental and social issues such as severe air pollution, rising income inequality, increasing numbers of product recalls, deteriorating environmental pollution, urgent needs related to healthcare and medical system reform, insufficiency of the social security system, and political corruption, among others. These grave environmental and social issues are thus leading shareholders to pay increasing attention to firms' social responsibility. As a result, investors may use their investment selections to force firms to fulfill their social responsibilities.

Third, since the stock markets in emerging countries are still in their early stages, investors in these markets are lack of experiences to make investment decisions based on a full evaluation of all stocks' financial performance on their own. Rather, a majority of them still rely on certain credible signals or follow peers' investment selections when making their own investment decisions. Hence, when the initial SRI index is launched in emerging markets, the announcement of the index may draw special attentions from investors who have stronger incentives to apply social criteria in their investment selection but are lack of experiences in making selections on their own. Signaling theory suggests that the higher awareness a signal (i.e., the announcement of an SRI index) has drawn and the stronger reliance emerging-market investors are on the signal (due to lack of investment experiences), the stronger signaling effect a new piece of information can create (Gulati and Higgins 2003; Higgins and Gulati 2006; Connelly et al. 2011).

Moreover, because the stock exchange company or the government can gather more information that is not accessible to outsiders such as investors, the SRI index provides additional credible information to investors, thereby helping them to reduce the information asymmetry and resolve their uncertainty regarding which firms are top CSR performers. According to signaling theory, the strength of a signal may change for different institutional environments. When institutional environment lacks highquality information needed to differentiate one firm from another, relevant stakeholders must search for additional information to assess firm capability (Su et al. 2016). Thus, when an SRI index is announced, stakeholders might have stronger incentive to use this additional information which may help reduce their uncertainty to a larger extent. In other words, the higher uncertainties that emerging-market investors are in face of, the stronger signaling effects the announcement of an SRI index can create (Spence 1973; Kirmani and Rao 2000).

Lastly, the SRI index may also help lessen investors' uncertainty regarding the financial performance of CSR firms. According to the screening process of the SRI index, ${ }^{4}$

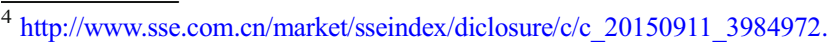
shtml.
}

investors may understand that firms listed in the SRI index have established not only outstanding performance in CSR, but also stable performance in the stock market. Even if investors are unclear about how the SRI index is constituted, they may infer from the index that the top performing CSR firms tend to have good management, and thus experience better financial performance (Waddock and Graves 1997). For example, as suggested in Sauer (1997), environmentally responsive firms are less likely to be subjected to environmental fines and lawsuits; product-responsive firms are less likely to encounter product recalls, and hence avoid costly settlements; and good corporate citizenship firms are more likely to create solid firm loyalty, which improves production efficiency, enhances creativity, and reduces production costs. Furthermore, sustaining good citizenship helps firms garner support from the government and the local community (Mishra and Suar 2010; Waddock and Graves 1997; Vidaver-Cohen and Altma 2000), which could further enhance the firm's competitive advantage and lead to better financial performance. In emerging markets, such benefits can be significantly higher due to the growing social and environmental issues and weak regulations. These benefits can lead to higher employee and customer loyalty, and in turn higher brand recognition, as well as increased sales and revenues.

Overall, because of the three unique characteristics of investors in emerging markets, the announcement of an SRI index can create strong signaling effects on stock markets, leading to positive abnormal returns accrued to firms included in the index. Thus, we propose the following hypothesis concerning the positive effect of the SRI index announcement in emerging markets.

H1: The announcement of an SRI index creates positive abnormal stock returns for firms listed in the SRI index of emerging markets.

\section{Moderating role of advertising and R\&D}

Advertising and $R \& D$ are two important marketing strategies that could potentially enhance or undermine the financial benefits of firms listed in the SRI index. Given the three unique characteristics of investors in emerging markets, it is crucial to understand how investors in these markets respond to the announcement of the SRI index for firms with different levels of advertising and $\mathrm{R} \& \mathrm{D}$ expenditures. For example, do investors respond more or less positively if the listed firms invest a large amount of money in advertising or R\&D? Understanding the interactions between marketing and CSR investments can help emerging-market firms effectively allocate resources to the most impactful strategy in value creation and appropriation.

Moderating role of advertising Based on CSR measures in the U.S. (i.e., the KLD database constructed by Kinder, 
Lydenberg and Domini Research and Analytics, Inc.), a recent study has documented that advertising investments complement CSR investment such that firms with large advertising expenditures can achieve higher financial returns from their CSR investments in the long run (Servaes and Tamayo 2013). This study argues that the lack of customers' awareness about a firm's CSR initiatives is a major problem, which handicaps consumers' ability to respond to CSR initiatives. Through large investments in advertising, firms can popularize their CSR programs and can enhance investors' awareness of their CSR contributions to society. As a result, investors are more likely to purchase stocks from these socially responsible firms, which strengthens the financial returns of the firms' CSR investment.

Different from Servaes and Tamayo (2013), who studied the long-term effects of CSR activities for firms with different advertising expenditures, we examine the immediate stock market responses to the SRI index announcement for firms with different advertising expenditures, where new information released from a signal can play a major role in the effect. Specifically, the larger the advertising expenditure, the more likely investors become more well-informed about the firms' CSR activities prior to the announcement of the SRI index. At the time when the SRI index is announced, the new information that investors can obtain become much less, which weakens the effect of the SRI index announcement. This suggests a substitutive relationship between advertising spending and the announcement of the SRI index.

More importantly, in emerging markets where regulations on faulty claims or deceptive advertising are substantially weak, and investors lack trust in firms' advertising, a firm's larger advertising expenditures may make investors more skeptical regarding whether the firm is truly socially responsible, which could potentially weaken the credibility of an SRI index and in turn the signaling effect of the SRI index announcement.

Corporations have long been criticized for their motives in carrying out CSR. For example, Williams (1986) has voiced concerns that CSR "is a strategy for selling, not for making a contribution to society." The in-depth interviews conducted by Webb and Mohr (1998) revealed that approximately half of the respondents believed that firms engaged in causerelated marketing campaigns to achieve firm-related gains (e.g., increasing sales and profits, garnering positive publicity). According to attribution theory (e.g., Heider 1958; Kelley 1967; Jones et al. 1972), people may attribute firms' CSR investments for extrinsic purposes (i.e., egoistic motives of improving the corporate or brand image). Attribution theory also suggests that the degree to which people are certain that the attribution is correct is a function of the relationship between the observed effect/behavior and the perceived cause (Settle and Golden 1974). In the context of CSR, the certainty of stakeholders' attributions regarding firms' motives for carrying out CSR can be reinforced or rejected by what they observe-for example, firms' marketing expenditures. A recent review study in CSR has also suggested that how stakeholders respond to a firm's CSR initiatives may depend on whether they perceive a fit between the CSR initiatives and the firm's marketing strategies (Bhattacharya and Sen 2004).

If investors observe excessive advertising expenditures by corporations in the SRI index, they may question whether such corporations are really driven by the maximization of all stakeholders' benefits (including the corporation itself, consumers, and the society), or whether they are driven only by maximization of the corporations' profits. Different from CSR initiatives that place top priority on benefitting society, advertising expenditures place top priority on benefitting corporations (i.e., corporate reputation and profits), which may not benefit society. Such a discrepancy between investments in CSR and large advertising expenditures may lead stakeholders to interpret the motivations of corporations' CSR as extrinsic rather intrinsic; hence, they may develop negative perceptions about the corporations' CSR actions. Extant studies have also argued this notion in a similar vein when studying the moderating role of advertising in other marketing strategic levers (Mizik and Jacobson 2003) or in firms' financial idiosyncratic risk (e.g., Luo and Bhattacharya 2009). They suggested that because advertising is more related to the process of value appropriation (i.e., extracting value in the marketplace from customers/rivals), as opposed to value creation, investors may interpret firms' CSR activities as being primarily for self-serving purposes rather than for social benefits when they observe that those included firms spend a large amount of money on advertising (to extract value by shifting value from other places).

As a result, such inconsistency between two signals from firms' investment in advertising and in CSR can weaken the signaling effect of the SRI index announcement. Hence, we propose a hypothesis concerning the negative moderating effect of advertising expenditures on the financial benefits of SRI inclusion.

H2: For firms listed in an SRI index, advertising expenditures weaken the positive impact of the SRI index on their abnormal stock returns in emerging economies.

Moderating role of R\&D Based on CSR measures in the U.S., two recent studies have also examined the moderating effect of R\&D on the long-term financial returns of CSR investment, but have demonstrated contradictory findings (Luo and Bhattacharya 2006; Hull and Rothenberg 2008). Specifically, the former showed a complementary effect of R\&D on the financial returns of CSR investment (Luo and Bhattacharya 2006), while the latter revealed a substitution effect (Hull and Rothenberg 2008). Luo and Bhattacharya 
(2006) argue for the complementary effect between CSR and $R \& D$ investments based on attribution theory, suggesting that an organization is regarded as legitimate when it satisfies and upholds both the social and pragmatic aspects of legitimacy. It is less likely that a company can generate a favorable impact from its CSR initiatives if it fails to innovate or offer quality products (i.e., the pragmatic aspect of legitimation). Hull and Rothenberg (2008), on the other hand, focus on the differentiation benefits that companies can achieve by investing in either CSR or R\&D, contending that companies with the best new products can differentiate from their competitors through their product offerings and need fewer incentives to attract customers. Less innovative companies, on the other hand, require other aspects to differentiate them from their competitors, and thus can boost their financial performance by improving their CSR performance.

However, since our research differs from these two prior studies by focusing on the immediate stock market responses to an SRI announcement, the central issue in our study involves how investors interpret the announcement of the SRI index if they can observe how much the listed firms have invested in R\&D. Compared to the advertising expenditure which is relatively more accessible to investors, $R \& D$ spending is an internal decision, which is often relatively less accessible to investors. Hence, although R\&D expenditure can also serve as a signal indicating whether a firm is socially responsible, which could potentially substitute the signaling effect of the SRI index announcement, we suggest that such a substitutive relationship between R\&D expenditure and the announcement of the SRI index tends to be weaker due to the low accessibility of R\&D information to investors.

Moreover, prior spending in R\&D can also serve as a legitimacy cue about how truthful the listed firms are in terms of social responsibility and in turn strengthen the credibility of the SRI index. If a low-level R\&D investment firm engages in CSR activities, as suggested in Luo and Bhattacharya (2006), consumers may consider CSR investment at the expense of R\&D investment; thus, they may question the motive of the firm carrying out the CSR. On the contrary, a large investment in R\&D may help generate favorable attributions regarding the firm's motivation to carry out CSR investments (i.e., intrinsic motive), because higher R\&D expenditures result in higher innovation and higher-quality products. Accordingly, it helps create increased customer satisfaction and loyalty and thus leads to a generally positive perception that stakeholders have in regard to the firm's social responsibility and better financial performance. In other words, because $R \& D$ is related more to a value-creation process, the firm's commitment to R\&D is often positively perceived as a socially responsible strategy (Mizik and Jacobson 2003).

In sum, in emerging markets where investors are more skeptical, a high level of R\&D investment reinforces the credibility of the SRI index and hence strengthens the signaling effect of an SRI index announcement on stock returns.

H3: For firms listed in an SRI index, R\&D expenditures strengthen the positive impact of the SRI index on their abnormal stock returns in emerging economies.

\section{Moderating role of global expansion}

Accompanying the rise of emerging markets, firms from these markets have begun to globalize by expanding abroad, acquiring and forming alliances with global marketers to acquire raw materials, gain new technologies, and access new markets (The Economist, Sept. 18, 2008; BCG 2009; McKinsey Quarterly 2015). ${ }^{5}$ Given that this emerging globalization trend has not only attracted attention from multinationals in developed countries, but also from those in their home countries, do investors in emerging markets perceive higher financial value for globalized firms in an SRI index than for domestic firms when the index is announced? Does such a moderating effect vary with the direction of global expansion (i.e., expansion to developed markets vs. developing markets)? Although extant studies have examined whether CSR investment or globalization can generate favorable financial returns, it is less certain as to how globalization complements or substitutes CSR investments, and if such a moderating relationship varies with the direction of global expansion.

We expect that investors will respond less positively to the announcement of an SRI index for listed firms that have expanded globally to developed countries than those that have expanded to developing countries. According to signaling theory, the signaling effect would be weaker when investors have lower uncertainty about firms' CSR activities. In the context of an SRI index announcement, investors would not be very surprised if those firms (that have expanded globally to developed countries) are included in the index. This is because these firms are expected to maintain global CSR standards when doing business in developed countries, as the CSR concept and practices have been well developed in Western countries, and the CSR standard has also evolved to a much higher/stricter standard regarding firms' conduct in CSR than that in emerging markets (e.g., stricter requirements in pollution control, higher standards in product quality and employee benefits, etc.). Investors understand that firms doing business in developed countries must have adopted CSR requirements in these markets. Doing business in developed countries can also impose

\footnotetext{
${ }^{5}$ Some notable examples of this globalization, as mentioned in The Economist (Sept. 18, 2008) include Lenovo, a Chinese computer hardware manufacturer; the Tata Group, an Indian conglomerate; Haier, a Chinese white-goods firm; Cemex, a Mexican cement company; Embraer, a Brazilian aircraft manufacturer; Infosys, an India software giant; and Ranbaxy, an Indian drug company, to name a few.
} 
higher costs of disseminating untruthful CSR reports. Hence, when the SRI index is announced, because investors face lower uncertainty regarding the CSR performance of those firms that have expanded globally to developed countries, the signaling effect of the SRI index announcement tends to be weaker.

However, investors may have higher uncertainty regarding if and how firms have implemented any CSR initiatives when they expand to less developed countries. In many developing countries, where economic development is still the central goal, local governments focus more on economic contributions from foreign investments rather than their CSR fulfillment. Similarly, regulations are also weak in many less developed markets with respect to CSR enforcement on pollution control, product quality control, and social benefits. Thus, when investors are aware of those firms that have done better in CSR when they expand to developing countries, investors may become more likely to reward these firms by investing in them. As a result, firms that have expanded to developing countries tend to benefit more from being listed in the index than those that have expanded to developed countries.

Furthermore, investors may also have higher uncertainty regarding the financial performance of CSR firms that have expanded to developing countries. Compared to the stable and transparent business environment in developed countries, the political and economic environment in many developing countries is volatile and ambiguous. Firms may encounter much more difficulties in doing business there and hence may experience fluctuating financial returns from their investments in developing countries. When investors see these firms in the SRI index, they may become more confident about the potential benefits from investing in these firms. Overall, due to higher levels of uncertainties about firms that have expanded to developing countries, the announcement of an SRI index can create higher financial returns for these global firms than their counterparts that have expanded to developed countries. Hence, we propose the following hypotheses regarding the moderating role of global expansion when considering the direction of expansion to developed versus developing countries.

H4: The announcement of an SRI index in emerging markets creates higher abnormal returns for those listed firms that have expanded globally to developing countries than those that have expanded globally to developed countries.

\section{Empirical analysis}

\section{Data}

We empirically examined the financial market responses to the announcement of the SRI indices in three emerging markets: Brazil, China, and South Africa. Specifically, China launched two initial SRI indices - the SSE Social Responsibility Index and the SZSE CSR PRICE INDEXon the Shanghai and Shenzhen stock exchanges on August 5, 2009, and August 3, 2009, respectively. ${ }^{6}$ Brazil and South Africa launched their initial SRI indices on the BM\&FBOVESPA stock exchange (i.e., Brazilian Corporate Sustainability Index, BCSI) and the Johannesburg stock exchange (i.e., JSE Socially Responsible Investment Index) on December 1, 2005, and May 19th, 2004, respectively. Based on their CSR performance, each of the two China SRI indices comprised top 100 publicly traded firms, whereas Brazil and South Africa listed 40 Brazilian and 51 South African firms in their respective indices.

When creating the SRI index, the Shanghai Stock Exchange selected candidates for the SSE SRI Index from the Governance Index constituents and excluded those firms whose traded amount per day falls into the bottom $20 \%$ of all publicly traded firms, as well as those firms with seriously negative CSR activities in the past year. Then the SSE calculated the social contribution value per share as the return/per share plus the value-added/per share, where the value-added/ per share equals the sum of the annual tax, salary payments, debit interest, and donations subtracting the fines and costs for negative activity (e.g., environmental pollution and irregular and unethical business). ${ }^{7}$ Similarly, the Shenzhen exchange selected candidates for the SRI index from firms whose governance evaluation score is higher than 75 (out of 100), and the calculation formula of the social attribution value is similar as that used by the Shanghai Stock Exchange.

In Brazil, the SRI index was developed by the Sustainability Study Center (SSC) at Fundação Getulio Vargas's Business School, a leading business school in Brazil, which evaluated the sustainability performance based on a questionnaire sent each year to up to 200 of Brazil's largest and most publically traded stocks (Lourenço and Branco 2013). In South Africa, following the constituent of the FTSE4Good, the JSE formulated the SRI index based on a set of about 70 criteria, grouped in terms of four overarching categories of corporate governance, society, environment and economy (Sonnenberg and Hamann 2006). The index is voluntary with no obligations to impose on companies. Participating companies are required to complete a questionnaire and submit annual reports and sustainability reports,

\footnotetext{
${ }^{6}$ See the SSE Social Responsibility Index at the Shanghai stock exchange at http://english.sse.com.cn/information/indices/list/s/singleIndex/000048/intro/ intro.shtml?indexCode $=000048$ and the SZSE CSR PRICE INDEX at the Shenzhen stock exchange at http://www.szse.cn/main/en/marketdata/ Indiceslist/\#.

${ }^{7}$ The value-added/per share is calculated based on whether the firm is capable of paying tax to government, paying salary to its employees, paying debit interests to debit owners and charity giving to the society, the facts that reflect whether a firm can fulfill its social responsibility to the society, their employees, and debit owners.
} 
based on which their CSR performance is assessed and scored (Sonnenberg and Hamann 2006).

To investigate the financial performance of firms listed in these SRI indices, we collected their daily stock prices and the market returns of respective stock exchanges from the Thomson Financial DataStream, a commonly used financial database for major stock markets all over the world (Lemmon and Lins 2003; Ince and Porter 2006). To isolate the impact of the SRI index announcements, we excluded those firms in the SRI indices that involved confounding events on the date of the SRI announcement, such as financial information disclosure, announcements of mergers and acquisitions, senior manager changes, new product launches, litigation clarification, and other important information releases. This led us to obtain a final sample of 145 Chinese firms, 22 Brazilian firms and 34 South African firms listed in their respective indices with a complete set of daily stock prices available.

\section{Event study methodology}

We adopted an event study methodology to examine the impact of SRI index announcements in emerging markets. Event study methodology has been widely used to analyze shortterm stock market returns in management, finance, accounting, and marketing (Kothari and Warner 2007; Kalaignanam et al. 2007; Chen et al. 2012; Swaminathan and Moorman 2009; Sood and Tellis 2009).

We estimated the abnormal returns to the event - the SRI index announcement-using the ex-post return of the stock during the course of the event window minus the normal expected return. Specifically, we estimated the normal expected returns using the market model (MacKinlay 1997) given by

$R_{i t}=\alpha_{i}+\beta_{i} R_{m t}+\varepsilon_{i t}$,

where $R_{i t}$ and $R_{m t}$ are the daily returns of stock $i(i=$ publicly traded firms listed in the SRI index) and the standard market portfolio at day $t$. Following the literature, we used $t=\{-270, \ldots,-21\}$ as the estimation window for predicting the normal returns of stock $i$, and we used the market portfolio in the estimation. We then applied the estimated $\hat{\alpha}_{i}$ and $\hat{\beta}_{i}$ in the event window to calculate the abnormal returns and cumulative abnormal returns of stock $i$ in the event window as:

$A R_{i t}=R_{i t}-\hat{\alpha}_{i}-\hat{\beta}_{i} R_{m t}$ and $C A R_{i t}=\sum_{t} A R_{i t}$

where $A R_{i t}$ and $C A R_{i t}$ denote the abnormal returns and cumulative abnormal returns at the event window $t$. To capture possible information leakage prior to the official announcement and possible delayed responses after the official announcement, we calculated the cumulative abnormal returns at different event windows (e.g., $[-1,1],[-2,2]$ and $[-3,3])$.

\section{Cross-section analysis}

We developed a regression model to further examine the impact of SRI index announcements on the abnormal returns of the listed firm $i$ in an SRI index by incorporating moderators and control variables. Specifically, four moderators were incorporated to test the moderating effects proposed in $\mathrm{H} 2-\mathrm{H} 4$ :

$$
\begin{aligned}
C A R_{i t}= & \alpha+\beta_{1} A D_{i t}+\beta_{2} R D_{i t}+\beta_{3} G L B_{i t}+\beta_{4} G L B \_D V P E D_{i t} \\
& +\beta_{5} O W N E R_{i t}+\beta_{6} S I Z E_{i t}+\beta_{7} C P F_{i t}+\beta_{8} R O A_{i t} \\
& +\beta_{9} F I D_{i t}+\beta_{10} S H_{i}+\xi_{i t}
\end{aligned}
$$

where $A D$ and $R D$ denote two strategic investments in advertising and $R \& D$, respectively. Two dummy variables, GLB and GLB_DVPED, denote whether a firm has expanded globally to a foreign market, and whether such a foreign market is a developed or a developing market.

We obtained data on advertising and R\&D expenditures from firms' annual financial reports in six months prior to the announcement of an SRI index from the Compustat Global in the WRDS database. Due to data availability for all three emerging markets, we followed extant literature (Collins and Han 2004; Ding et al. 2007; Ptok et al. 2018) and used firms' administrative and selling expenses as a proxy for advertising spending. Both advertising and R\&D expenditures (i.e., $A D$ and $R D$ ) are then adjusted by firms' sales to make it comparable across different firms (i.e., the advertising and R\&D expenditures are divided by firms' sales, respectively). We identified whether and where a listed firm in the index has expanded globally, based on the Worldwide Mergers, Acquisitions, and Alliances databases from the Security Data Company (SDC). We then measured GLB as 1 when the firm has completed a merger or acquisition (M\&A) prior to the announcement date, and we measured GLB_DVPED as 1 when the foreign firm merged or acquired was in developed countries. Following Burgess and Steenkamp (2006), we used the FTSE Group's classification of "Developed Markets" to classify 24 developed countries in our sample, including the U.S., the U.K., Canada, Japan, France, Australia, Germany, the Netherlands, Switzerland, Sweden, Italy, Belgium, Finland, Spain, Norway, Denmark, Iceland, New Zealand, Austria, Luxembourg, Greece, Portugal, Hong Kong, and Singapore. All other countries are considered as developing countries.

We incorporated five control variables to capture the potential impact of these control variables on the listed firms' abnormal returns. As shown in the literature, firm size and ownership can negatively influence the market performance of CSR firms (McWilliams and Siegel 2000; Graves and Waddock 1994; Johnson and Greening 1999; Wang and Li 2016). For example, extant literature have shown that CSR firms with larger size and larger state ownership tend to have lower financial market values as those with lower size and 
lower state ownership (McWilliams and Siegel 2000; Graves and Waddock 1994; Johnson and Greening 1999; Wang and Li 2016). Data on firm size were collected from firms' annual financial reports in the first six months of 2009. Following the literature (Li and Zhang 2010; Zhang et al. 2010), we used the logarithm of total assets to measure firm size. We classified firms as private or state-owned, according to their ownership structure as reported in the stock exchanges, and measured $O W N E R$ as a dummy variable such that $O W N E R=1$ indicates state-owned firms, and $O W N E R=0$ otherwise.

We also classified firms into consumer-product firms and industrial-product firms, based on the classification in Porter (p. 428, Porter 1974). Specifically, we categorized $C P F$ as 1 when firms belong to industries in which the end users are individual consumers, and as zero when firms belong to industrial-product firms. The consumer-product firms included consumer discretionary spending, consumer staples, pharmaceuticals, and consumer electronics, whereas the industrialproduct firms included energy, materials, and industrial equipment manufacturers, among others. We incorporated this dummy variable of $C P F$ to capture the potential differential responses of stock markets to consumer-product firms (vs. industrial-product firms) as individual investors, which are also end-users, may have more knowledge about consumerproduct firms based on their daily consumption experiences and hence respond more strongly to the stocks of consumerproduct firms than to those industrial-product firms.

Lastly, following the CSR literature (Khan et al. 2013; Mishra and Suar 2010), we also incorporated the return on the assets of firms (i.e., $R O A$ ) in the estimation to capture the potential variations in stock market responses to firms with different levels of financial capability. To capture the potential different stock market responses in the Shanghai, Shenzhen, Brazilian and South African stock exchanges, we incorporated three dummy variables such as $S H, B R$, and $S A$ to indicate whether the firm is listed on the Shanghai, or Brazilian or
South African stock exchange. Table 2 summarizes the variables used in the regression model and their descriptive statistics.

\section{Results}

\section{Main results}

To study stock market responses to the initial announcements of an SRI index, we first examined the cumulative abnormal returns of all firms listed in the SRI indices at various event windows (e.g., $[-1,+1],[-2,+2]$ and $[-3,+3])$. We presented the cumulative abnormal returns at different event windows in Table 3 and tested their significance using multiple t-test statistics.

As shown in Table 3, the cumulative abnormal returns of firms that were selected for the SRI index are significantly positive in all event windows. For example, on the SRI index announcement date, the average abnormal returns are $0.54 \%$ and are consistently significant. If we focus on relatively wider windows (e.g., $[-3,3])$, the average abnormal returns are also significantly positive (e.g., the average cumulative abnormal returns are $1.8 \%$ at the event window of $[-3,3]$ ) and are relatively higher than that on the event date, indicating that the effect also holds 3 days prior to and 3 days after the announcement date. These results support H1, suggesting that the announcement of an SRI index creates significantly positive abnormal returns for firms listed in the index in emerging markets.

Given the cumulative abnormal returns reported in Table 3, we then conduct a cross-sectional analysis using the regression model (3) to examine the moderating effects proposed in $\mathrm{H} 2-\mathrm{H} 4$ at various event windows. Given that the event occurs on the same date for all firms included in the analysis, heteroscedasticity might be an issue in our data. To correct
Table 2 Descriptive statistics of variables

\begin{tabular}{lllll}
\hline Variables & Mean & Std. & Min. & Max. \\
\hline Advertising $(A D)$ & 0.125 & 0.094 & 0 & 0.518 \\
R\&D Expenditure $(R D)$ & 0.006 & 0.014 & 0 & 0.095 \\
Global-Expansion (GLB) & 0.228 & 0.421 & 0 & 1 \\
Global-Expansion to Developed Country (GLB_DVPED) & 0.104 & 0.306 & 0 & 1 \\
Firm Size (SIZE) & 9.208 & 1.658 & 6.227 & 14.907 \\
Ownership (OWNER) & 0.502 & 0.501 & 0 & 1 \\
Consumer-Product Firms (CPF) & 0.179 & 0.384 & 0 & 1 \\
Return on Assets (ROA) & 0.067 & 0.053 & -0.033 & 0.305 \\
Foreign Investor Holding (FID) & 0.134 & 0.342 & 0 & 1 \\
Shanghai Dummy (SH) & 0.338 & 0.474 & 0 & 1 \\
Brazil Dummy (BR) & 0.109 & 0.312 & 0 & 1 \\
South Africa Dummy (SA) & 0.169 & 0.375 & 0 & 1 \\
\hline
\end{tabular}


Table 3 Cumulative abnormal returns to the SRI index announcement

\begin{tabular}{lcc}
\hline Event Window & CAR & $\mathrm{t}$-Statistic \\
\hline$[0]$ & .0054 & $2.940^{* *}$ \\
{$[0,1]$} & .0062 & $2.380^{* *}$ \\
{$[0,2]$} & .0169 & $3.450^{* * *}$ \\
{$[-1,1]$} & .0076 & $2.450^{* *}$ \\
{$[-1,2]$} & .0120 & $3.450^{* * * *}$ \\
{$[-2,1]$} & .0090 & $2.480^{* *}$ \\
{$[-2,2]$} & .0143 & $3.390^{* * * *}$ \\
{$[-2,3]$} & .0177 & $3.830^{* * *}$ \\
{$[-3,2]$} & .0150 & $3.350^{* * * *}$ \\
{$[-3,3]$} & .0179 & $3.780^{* * *}$ \\
\hline Sample size $N=145 .{ }^{* * *}: p<.01 ;{ }^{* *}:$ \\
$p<.05$. The event window 0 represents \\
the date of the SRI index announcement
\end{tabular}

for a potential heteroscedasticity issue, we estimate our regression model using heteroscedasticity-consistent standard errors. Furthermore, to solve the missing value issue in the variable of $R \& D$, we estimate the regression model using the zero-replaced $\mathrm{R} \& \mathrm{D}$, by following the accounting and finance literature which have generally assumed that firms choosing not to disclose the R\&D information are those with zero or immaterial corporate R\&D (Koh and Reeb 2015). ${ }^{8}$ As reported in Table 4, the estimation results concerning the moderating effects are consistent across four event windows. Since the event study at the event window of $[-3,3]$ provides the highest abnormal returns, we discuss our results concerning the moderating effects based on Estimation 4 in Table 4.

With regard to the moderating effect of advertising and R\&D, we found that the coefficient of advertising is significantly negative $\left(\beta_{1}=-0.184, p<0.01\right)$, whereas the coefficient of $\mathrm{R} \& \mathrm{D}$ expenditures is significantly positive $\left(\beta_{2}=\right.$ $0.580, p<0.05$ ). These results provide empirical evidence in support of $\mathrm{H} 2$ and $\mathrm{H} 3$, suggesting that while large R\&D expenditures significantly strengthen the impact of the SRI index announcement on stock returns in emerging markets, large advertising expenditures significantly weaken the positive stock market responses to the SRI index announcement.

Concerning the moderating effect of global expansion proposed in H4, our results revealed interesting findings: the coefficient of global expansion $(G L B)$ is significantly positive $\left(\beta_{3}=0.028, p<0.05\right)$, but the coefficient of global expansion to developed countries (GLB_DVPED) is significantly negative $\left(\beta_{4}=-0.034, p<0.1\right)$. These results provide empirical evidence in support of $\mathrm{H} 4$, implying that shareholders in emerging markets are concerned not only about whether emerging-market firms have a presence in the global markets, but also about where these firms have expanded globally to

\footnotetext{
${ }^{8}$ We also estimated our model using the mean-replaced R\&D and obtain consistent results as using the zero-replaced $\mathrm{R} \& \mathrm{D}$. The estimation results using the mean-replaced $R \& D$ are available upon request.
}

(i.e., developed vs. developing markets) when evaluating firms' CSR performance. These shareholders reward those firms that have contributed to other developing countries even more so.

\section{Robustness of results}

We first examined the robustness and validity of our key findings by using two subsamples: (1) China sample and (2) Brazil and South Africa samples combined. We combined the Brazil and South Africa samples together due to the small number of firms included in these two samples. Our analyses using these two subsamples also revealed significantly positive abnormal returns accrued to firms listed in the SRI indices, as presented in Table 5 of Appendix 1. For example, the top Chinese CSR performers obtained as much as $2.8 \%$ of abnormal returns at the event windows of $[-3,3]$, while Brazilian and South African firms listed in the SRI indices earned on average about $0.9 \%$ of abnormal returns in three days after the SRI indices are announced. Concerning the moderating effects of marketing variables, as shown in Table 6 of Appendix 1, our estimation using the China sample also demonstrated consistent findings as in Table 4. Due to the small number of listed firms in Brazil and South Africa markets, we found consistent signs for most of moderate variables (i.e., advertising and R\&D) though insignificant.

We then examined the robustness of our key findings by using different market portfolios, testing the endogeneity and the generalizability. Due to data availability, we performed these examinations by using the China sample. Specifically, we used four different market portfolios to examine the robustness of our findings: (1) a tradable market value-weighted market return, (2) the market capitalization-weighted market return, (3) the CSI 800, and (4) the CSI $300 .{ }^{9}$ The first two market portfolios are compiled by using all stocks on the Shanghai and Shenzhen stock exchanges, while the latter two are compiled based on a sample of major stocks to reflect market performance on the Shanghai and Shenzhen securities markets. We collected the market returns of these different market portfolios from a commonly used financial database for the Chinese stock markets-the RESSET Financial Research Database (e.g., Guo and Fung 2011; Huang and Li 2012). As shown in Table 7 of Appendix 2, the cumulative abnormal returns, derived at different event windows and based on these four market portfolios, are significantly positive and consistent with the cumulative abnormal returns in Table 3. The cross-sectional analysis using the cumulative abnormal returns based on the four market portfolios, as

\footnotetext{
${ }^{9}$ CSI 800 is composed of CSI 300 and CSI 500 and aims to comprehensively reflect the price fluctuations and performance of large-, mid-, and small-cap companies on the Shanghai and Shenzhen securities markets. The CSI 300 is a capitalization-weighted stock market index designed to replicate the performance of 300 stocks traded on the Shanghai and Shenzhen stock exchanges.
} 
Table 4 Cross-sectional analysis of the cumulative abnormal returns

\begin{tabular}{|c|c|c|c|c|c|}
\hline Variable & $\begin{array}{l}\text { Event } \\
\text { Window } \\
[-2,1])\end{array}$ & $\begin{array}{l}\text { Event } \\
\text { Window } \\
[-2,2])\end{array}$ & $\begin{array}{l}\text { Event } \\
\text { Window } \\
{[-2,3]}\end{array}$ & $\begin{array}{l}\text { Event } \\
\text { Window } \\
{[-3,2]}\end{array}$ & $\begin{array}{l}\text { Event } \\
\text { Window } \\
{[-3,3]}\end{array}$ \\
\hline Intercept & $\begin{array}{l}0.063^{* *} \\
(0.029)\end{array}$ & $\begin{array}{l}0.084^{* * * *} \\
(0.032)\end{array}$ & $\begin{array}{l}0.116^{* * * *} \\
(0.034)\end{array}$ & $\begin{array}{l}0.106^{* * *} \\
(0.036)\end{array}$ & $\begin{array}{l}0.138^{* * * *} \\
(0.038)\end{array}$ \\
\hline Advertising (AD) & $\begin{array}{l}-0.084^{* *} \\
(0.043)\end{array}$ & $\begin{array}{l}-0.126^{* * *} \\
(0.051)\end{array}$ & $\begin{array}{l}-0.149^{* * *} \\
(0.054)\end{array}$ & $\begin{array}{l}-0.162^{* * *} \\
(0.054)\end{array}$ & $\begin{array}{l}-0.184^{* * * *} \\
(0.054)\end{array}$ \\
\hline$R \& D$ Expenditure $(R D)$ & $\begin{array}{l}0.476 \\
(0.328)\end{array}$ & $\begin{array}{l}0.606^{* *} \\
(0.299)\end{array}$ & $\begin{array}{l}0.635^{* *} \\
(0.258)\end{array}$ & $\begin{array}{l}0.551^{* *} \\
(0.286)\end{array}$ & $\begin{array}{l}0.580^{* *} \\
(0.253)\end{array}$ \\
\hline Global-Expanded (GLB) & $\begin{array}{l}0.028^{* *} \\
(0.011)\end{array}$ & $\begin{array}{l}0.033^{* *} \\
(0.010)\end{array}$ & $\begin{array}{l}0.031^{* *} \\
(0.012)\end{array}$ & $\begin{array}{l}0.031^{\text {**** }} \\
(0.011)\end{array}$ & $\begin{array}{l}0.028^{* * *} \\
(0.013)\end{array}$ \\
\hline $\begin{array}{l}\text { Global-Expanded to Developed Country } \\
\quad\left(G L B \_D V P E D\right)\end{array}$ & $\begin{array}{l}-0.029^{*} \\
(0.016)\end{array}$ & $\begin{array}{l}-0.032^{*} \\
(0.019)\end{array}$ & $\begin{array}{l}-0.041^{* *} \\
(0.021)\end{array}$ & $\begin{array}{l}-0.025 \\
(0.016)\end{array}$ & $\begin{array}{l}-0.034^{*} \\
(0.018)\end{array}$ \\
\hline SIZE & $\begin{array}{l}-0.007^{* *} \\
(0.003)\end{array}$ & $\begin{array}{l}-0.008^{\text {*** }} \\
(0.003)\end{array}$ & $\begin{array}{l}-0.011^{* * * *} \\
(0.003)\end{array}$ & $\begin{array}{l}-0.010^{* * * *} \\
(0.004)\end{array}$ & $\begin{array}{l}-0.013^{\text {*** }} \\
(0.004)\end{array}$ \\
\hline OWNERSHIP (OWNER) & $\begin{array}{l}0.011 \\
(0.010)\end{array}$ & $\begin{array}{l}0.007 \\
(0.011)\end{array}$ & $\begin{array}{l}-0.0001 \\
(0.011)\end{array}$ & $\begin{array}{l}0.008 \\
(0.011)\end{array}$ & $\begin{array}{l}0.001 \\
(0.012)\end{array}$ \\
\hline Consumer-Product Firms (CPF) & $\begin{array}{l}0.013 \\
(0.009)\end{array}$ & $\begin{array}{l}0.025^{* * *} \\
(0.009)\end{array}$ & $\begin{array}{l}0.038^{* * * *} \\
(0.011)\end{array}$ & $\begin{array}{l}0.031^{* * * *} \\
(0.011)\end{array}$ & $\begin{array}{l}0.043^{\text {**** }} \\
(0.011)\end{array}$ \\
\hline$R O A$ & $\begin{array}{l}-0.082 \\
(0.088)\end{array}$ & $\begin{array}{l}-0.026 \\
(0.100)\end{array}$ & $\begin{array}{l}-0.009 \\
(0.124)\end{array}$ & $\begin{array}{l}-0.012 \\
(0.101)\end{array}$ & $\begin{array}{l}0.004 \\
(0.121)\end{array}$ \\
\hline Foreign Investor Holding (FID) & $\begin{array}{l}0.020 \\
(0.014)\end{array}$ & $\begin{array}{l}0.020 \\
(0.014)\end{array}$ & $\begin{array}{l}0.019 \\
(0.014)\end{array}$ & $\begin{array}{l}0.026^{*} \\
(0.014)\end{array}$ & $\begin{array}{l}0.025^{*} \\
(0.013)\end{array}$ \\
\hline Brazil (BR) & $\begin{array}{l}-0.004 \\
(0.011)\end{array}$ & $\begin{array}{l}-0.005 \\
(0.013)\end{array}$ & $\begin{array}{l}0.004 \\
(0.016)\end{array}$ & $\begin{array}{l}-0.011 \\
(0.013)\end{array}$ & $\begin{array}{l}-0.002 \\
(0.015)\end{array}$ \\
\hline South Africa (SA) & $\begin{array}{l}-0.004 \\
(0.013)\end{array}$ & $\begin{array}{l}-0.008 \\
(0.013)\end{array}$ & $\begin{array}{l}-0.017 \\
(0.014)\end{array}$ & $\begin{array}{l}-0.030^{* *} \\
(0.011)\end{array}$ & $\begin{array}{l}-0.038^{* * *} \\
(0.014)\end{array}$ \\
\hline Shanghai (SH) & $\begin{array}{l}0.026 \\
(0.010)\end{array}$ & $\begin{array}{l}0.020^{*} \\
(0.011)\end{array}$ & $\begin{array}{l}0.033^{\text {**** }} \\
(0.011)\end{array}$ & $\begin{array}{l}0.018 \\
(0.011)\end{array}$ & $\begin{array}{l}0.031^{* * * *} \\
(0.011)\end{array}$ \\
\hline R-Square & 0.130 & 0.166 & 0.239 & 0.211 & 0.289 \\
\hline
\end{tabular}

${ }^{* * *}: p<0.01 ;{ }^{* *}: p<0.05 ;$ and ${ }^{*}: p<0.1$. Numbers in parentheses are heteroscedasticity-consistent standard errors. Number of firms in the combined sample of three emerging markets, $N=185$, due to missing data presented in Table 8 of Appendix 2, also demonstrated consistent patterns regarding the moderating effects of strategic investments in advertising, $\mathrm{R} \& \mathrm{D}$ and globalization.

Furthermore, we tested whether our cross-sectional analysis was subject to the endogeneity issue (i.e., sample selection bias). Potential sample selection bias might exist because the SRI index involves a selection of public firms on the Shanghai and Shenzhen stock exchanges that are outstanding in fulfilling their social responsibility. If sample selection bias exists, the moderating effects of our key marketing variables (i.e., advertising, R\&D and global expansion) identified in Table 4 may be also biased. To address this issue, we applied the Heckman two-stage estimation approach when analyzing Eq. 3. Specifically, we first estimated a selection equation of how likely a publicly traded firm on the Shanghai and Shenzhen stock exchanges is selected in the SRI index, and then we incorporated a correction term, derived based on the first-stage estimation, into the second-stage estimation of
Eq. 3 to correct for potential selection bias. In the first stage of the estimation, we modeled the selection of publicly traded firms in the SRI index to be a function of (1) each firm's CSR score (in terms of how comprehensive its CSR report is), (2) each firm's ROA, (3) the industry average CSR score, (4) the industry competition, (5) the market institution development, and (6) all other variables used in Eq. 3 by following the literature on Chinese CSR (e.g., Ghoul et al. 2011; Koh et al. 2014; Wang et al. 2008; Chen et al. 2017; McGuinness et al. 2017). In particular, the key variable - an individual firm's CSR score-was collected from the Chinese Corporate Social Responsibility Database (i.e., CCSR), a third-party evaluation of firms' CSR activities compiled by a financial service company, Efindata, and widely used for studying the CSR activities of Chinese companies (e.g., Chen et al. 2017; McGuinness et al. 2017). The measurements and data sources of all other variables are reported in Table 9 of Appendix 3. Table 10 of Appendix 3 presents our two-stage 
estimation results. As shown, the inverse Mills' ratio is not significant, indicating that sample selection bias is not a severe issue in the estimation of Eq. 3. More importantly, we found consistent results regarding the moderating effects of advertising, R\&D and global expansion when the correction term was controlled.

Lastly, to examine the generalizability of our key findings, we extended our empirical analysis to a longer time period of the China SRI index. Specifically, we expanded our sample to include all listed firms in the SRI indices on Shanghai and Shenzhen stock exchanges from 2009 to 2017. We presented our empirical analysis results by using this nine-year China sample in Appendix 4. As presented in Table 11 of Appendix 4 , our analyses using the nine-year China sample also revealed positive abnormal returns accrued to firms included in the Shanghai and Shenzhen SRI indices when these two indices were announced in every year from 2009 to 2017 . Table 12 of Appendix 4 also demonstrated consistent findings concerning the moderating effects of marketing investments. Overall, our analyses using two subsamples, different market portfolios and our tests for endogeneity demonstrate the robustness and generalizability of our key finding regarding the positive stock market responses to the announcements of SRI indices over years and across three emerging markets.

\section{General discussion}

In emerging markets, where economic development is the main driving force of many corporations, do stakeholders (e.g., consumers and investors) care about whether firms fulfill their social responsibility? Furthermore, do they consider this factor in their decision making (i.e., purchase and investment decisions)? As organizations (i.e., governments and NGOs) continue to encourage and disclose CSR as more firms engage in CSR programs in emerging markets, there is a pressing need to understand whether and how these markets respond to CSR initiatives (e.g., an SRI index). This study conceptualizes and empirically examines a framework concerning (1) short-term financial market responses to the announcement of an SRI index that has been recently launched in emerging markets, (2) the differential impacts of listed firms with different types of market presence (i.e., global vs. domestic, global expansion to developed vs. developing markets), and (3) the interactive roles of strategic investments that strengthen/weaken market responses to the announcement of an SRI index.

\section{Managerial implications}

Our findings provide several managerial implications for firms and governments in emerging markets. First, our findings provide enlightening evidence to firms carrying out CSR in emerging markets. Our finding that investors respond positively to the announcement of an SRI implies that CSR is not merely a strategy that can create financial value, but one that can also build a positive brand image to attract investors in emerging markets. This result is particularly inspiring for both domestic and multinational companies in emerging markets. Although CSR is a relatively new concept that is challenging to carry out for domestic firms, it is a valuable endeavor. In particular, when it is costly or difficult to utilize traditional strategies (e.g., advertising) to create market awareness, engaging in CSR can be a useful and often easier choice. Practicing CSR can build trust and can enhance firms' reputation because these companies can achieve a better understanding of their consumers via CSR and can then incorporate local communities' needs into their product offerings and services.

For multinational companies operating in emerging markets, our findings suggest that devoting the same or even more effort to CSR, rather than cutting back in emerging markets due to low CSR standards, is not only necessary, but also provides financial and branding rewards. For example, although these companies may understand traditional brandbuilding strategies better and are often capable of conducting marketing strategies, it is often difficult to reach consumers who are fragmented, who have heterogeneous preferences, or who have no access to traditional media (i.e., newspaper, TV, and Internet). In contrast, carrying out CSR can be an effective alternative for creating awareness and building a corporate reputation. As pointed out in The African Executive (Nov. 12, 2012), engaging in CSR by partnering with NGOs in emerging markets can help multinationals (1) understand the underlying needs in emerging markets, (2) reach consumers in the "informal sector," which is neither taxed nor monitored by the government, (3) strengthen relationships with local partners through "social contracts" when there is a lack of regulation enforcing them, (4) build good public relations with local consumers, and (5) enhance the legitimacy of doing business in emerging nations. ${ }^{10}$

Second, our findings provide guidance for firms to conduct CSR effectively. Specifically, our findings imply that while carrying out CSR is financially valuable, the value of CSR is not unconditional, and not all firms may benefit from carrying out CSR equally. Our finding that strategic investments moderate the abnormal returns accrued by the announcement of an SRI index demonstrates the conditions under which firms can benefit the most from engaging in CSR. That is, firms with large expenditures in globalization (i.e., in less developed countries) benefit more than those expanded to developed countries and/or with large advertising expenditures. Thus,

\footnotetext{
10 "Social contract" in the article refers to the beliefs, unwritten rules of behavior, familial ties, and social and moral norms of a given community, as opposed to the legal and governmental regulations.
} 
when allocating limited resources to CSR and marketing strategies, it is important for firms to consider CSR and other strategic investments simultaneously rather than independently. In addition, when selecting local partners, it is beneficial for multinationals to consider whether the local partners are carrying out CSR effectively as an important selection criterion in emerging markets.

Finally, our findings provide implications to policymakers in emerging markets. Although the financial markets in emerging markets are still in their early stages, our findings illustrate the notion that launching an SRI index to disclose firms that are implementing CSR more proficiently can be an effective instrument for encouraging firms to contribute to society and pursue sustainable development. Thus, local governments can consider more CSR initiatives using financial instruments, such as SRI funds, to continue advocating for the importance of social responsibility to firms.

\section{Future research}

Our study has several limitations that provide opportunities for future research. As one of first studies examining the financial values of an SRI index in emerging markets, this study focuses on the stock market responses to the announcement of SRI indices in the fastest-growing emerging markets - China, Brazil, and South Africa. While our analysis using the nineyear China sample demonstrates positive stock market responses to the release of the SRI index in long run, it would be more insightful if future studies could examine the longterm financial performance of SRIs using other financial measurements such as Tobin Q and also investigate the moderating effects of marketing over a longer time span. Based on the empirical evidence provided from our analysis using the nineyear China sample, one could expect a promising financial return in long run to firms' CSR investments. Furthermore, future research can also examine the differential effects of the release of SRI on those firms which have been dropped or newly added on the SRI index in emerging markets. It would be particularly valuable if future research can demonstrate how stock markets react to those firms that have dropped from the SRI index due to their poor CSR performance and how their marketing investment moderates these stock market responses.

Acknowledgements This research is partially funded by a research grant from the National Natural Science Foundation of China under project nos. 71272174 and 71672047.

\section{Appendix 1: Empirical analysis of subsamples}

Table 5 Cumulative abnormal returns to the sri announcements in emerging markets

\begin{tabular}{lllllll}
\hline & CAR[0] & CAR $[0,1]$ & CAR $[0,2]$ & CAR $[-1,1]$ & CAR [-2,2] & CAR $[-3,3]$ \\
\hline China & $0.005^{* * *}$ & $0.006^{* * *}$ & $0.021^{* * *}$ & $0.010^{* * *}$ & $0.010^{* * * *}$ & $0.028^{* * *}$ \\
BR\&SA & $0.0056^{* *}$ & $0.0064^{* *}$ & $0.0088^{*}$ & 0.0017 & 0.0009 & -0.0091 \\
\hline
\end{tabular}

${ }^{* * *}: p<0.01 ;{ }^{* *}: p<0.05$; and ${ }^{*}: p<0.1$. Number of firms in the combined sample of Brazil and South Africa, $N=56$. Number of firms in the China sample, $\mathrm{N}=145$

Table 6 Cross-sectional analysis of cumulative abnormal returns (using subsamples)

\begin{tabular}{|c|c|c|c|c|}
\hline \multirow[t]{2}{*}{ Variable } & \multicolumn{2}{|c|}{ Using Combined Sample of Brazil and South Africa } & \multicolumn{2}{|l|}{ Using China Sample } \\
\hline & Event Window [0] & Event Window $[0,1]$ & Event Window $[-2,2]$ & Event Window $[-3,3]$ \\
\hline Intercept & $\begin{array}{l}0.015 \\
(0.038)\end{array}$ & $\begin{array}{l}0.016 \\
(0.052)\end{array}$ & $\begin{array}{l}0.087^{* *} \\
(0.035)\end{array}$ & $\begin{array}{l}0.135^{* * *} \\
(0.044)\end{array}$ \\
\hline Advertising $(A D)$ & $\begin{array}{l}-0.017 \\
(0.043)\end{array}$ & $\begin{array}{l}-0.093^{*} \\
(0.065)\end{array}$ & $\begin{array}{l}-0.149^{* * * *} \\
(0.065)\end{array}$ & $\begin{array}{l}-0.216^{* * *} \\
(0.070)\end{array}$ \\
\hline$R \& D$ Expenditure $(R D)$ & $\begin{array}{l}0.594 \\
(0.368)\end{array}$ & $\begin{array}{l}0.625 \\
(0.833)\end{array}$ & $\begin{array}{l}0.593^{*} \\
(0.335)\end{array}$ & $\begin{array}{l}0.579^{* * *} \\
(0.279)\end{array}$ \\
\hline Global-Expansion $(G L B)$ & $\begin{array}{l}0.002 \\
(0.006)\end{array}$ & $\begin{array}{l}-0.005 \\
(0.010)\end{array}$ & $\begin{array}{l}0.045^{* * * *} \\
(0.012)\end{array}$ & $\begin{array}{l}0.040^{* * *} \\
(0.016)\end{array}$ \\
\hline $\begin{array}{l}\text { Global-Expanded to Developed } \\
\text { Country (GLB DVPED) }\end{array}$ & $\begin{array}{l}0.015 \\
(0.009)\end{array}$ & $\begin{array}{l}0.011 \\
(0.013)\end{array}$ & $\begin{array}{l}-0.056^{*} \\
(0.031)\end{array}$ & $\begin{array}{l}-0.063^{* *} \\
(0.027)\end{array}$ \\
\hline SIZE & $\begin{array}{l}-0.001 \\
(0.003)\end{array}$ & $\begin{array}{l}0.001 \\
(0.005)\end{array}$ & $\begin{array}{l}-0.010^{* * * *} \\
(0.004)\end{array}$ & $\begin{array}{l}-0.013^{* * *} \\
(0.005)\end{array}$ \\
\hline
\end{tabular}


Table 6 (continued)

\begin{tabular}{|c|c|c|c|c|}
\hline \multirow[t]{2}{*}{ Variable } & \multicolumn{2}{|c|}{ Using Combined Sample of Brazil and South Africa } & \multicolumn{2}{|l|}{ Using China Sample } \\
\hline & Event Window [0] & Event Window $[0,1]$ & Event Window $[-2,2]$ & Event Window $[-3,3]$ \\
\hline OWNERSHIP (OWNER) & $\begin{array}{l}0.005 \\
(0.008)\end{array}$ & $\begin{array}{l}0.001 \\
(0.011)\end{array}$ & $\begin{array}{l}0.008 \\
(0.012)\end{array}$ & $\begin{array}{l}0.003 \\
(0.013)\end{array}$ \\
\hline Consumer-Product Firms (CPF) & $\begin{array}{l}-0.010 \\
(0.007)\end{array}$ & $\begin{array}{l}-0.006 \\
(0.010)\end{array}$ & $\begin{array}{l}0.037^{* * * *} \\
(0.010)\end{array}$ & $\begin{array}{l}0.056^{* * * *} \\
(0.013)\end{array}$ \\
\hline$R O A$ & $\begin{array}{l}-0.024 \\
(0.081)\end{array}$ & $\begin{array}{l}-0.075 \\
(0.108)\end{array}$ & $\begin{array}{l}0.025 \\
(0.121)\end{array}$ & $\begin{array}{l}0.076 \\
(0.144)\end{array}$ \\
\hline Foreign Investor Holding (FID) & $\begin{array}{l}0.010 \\
(0.008)\end{array}$ & $\begin{array}{l}0.009 \\
(0.015)\end{array}$ & $\begin{array}{l}0.024 \\
(0.016)\end{array}$ & $\begin{array}{l}0.030^{* *} \\
(0.014)\end{array}$ \\
\hline Brazil & $\begin{array}{l}-0.013^{*} \\
(0.007)\end{array}$ & $\begin{array}{l}-0.018 \\
(0.012)\end{array}$ & & \\
\hline Shanghai & & & $\begin{array}{l}0.021^{*} \\
(0.011)\end{array}$ & $\begin{array}{l}0.031^{* * * *} \\
(0.011)\end{array}$ \\
\hline R-square & 0.263 & 0.239 & 0.189 & 0.270 \\
\hline
\end{tabular}

${ }^{* * * *}: p<0.01{ }^{* *}: p<0.05 ;$ and ${ }^{*}: p<0.1$. Numbers in parentheses are heteroscedasticity-consistent standard errors. Number of firms in the combined sample of Brazil and South Africa is reduced to $N=39$, due to missing data. Number of firms in the China sample $\mathrm{N}=145$

\section{Appendix 2: Empirical analysis of China sample using different market portfolios}

Table 7 Cumulative abnormal returns to the sri index announcement (using different market portfolios)

\begin{tabular}{|c|c|c|c|c|}
\hline Event Window & MRET_TMV ${ }^{\mathrm{a}}$ & MRET_MC & CSI $800^{\circ}$ & CSI $300^{\mathrm{d}}$ \\
\hline 0 & $\begin{array}{l}0.003 \\
(0.002)\end{array}$ & $\begin{array}{l}0.005^{* * *} \\
(0.002)\end{array}$ & $\begin{array}{l}0.007^{* * * *} \\
(0.002)\end{array}$ & $\begin{array}{l}0.008^{* * * *} \\
(0.002)\end{array}$ \\
\hline$[0,1]$ & 0.002 & $0.006^{*}$ & $0.010^{* * * * *}$ & $0.012^{* * * * *}$ \\
\hline$[-1,0]$ & $\begin{array}{l}(0.003) \\
0.009^{* * * *}\end{array}$ & $\begin{array}{l}(0.003) \\
0.009^{* * *}\end{array}$ & $\begin{array}{l}(0.003) \\
0.012^{* * * *}\end{array}$ & $\begin{array}{l}(0.003) \\
0.015^{* * * *}\end{array}$ \\
\hline$[-1,1]$ & $\begin{array}{l}(0.003) \\
0.008^{*} \\
(0.004)\end{array}$ & $\begin{array}{l}(0.003) \\
0.010^{* * *} \\
(0.004)\end{array}$ & $\begin{array}{l}(0.003) \\
0.016^{* * *} \\
(0.004)\end{array}$ & $\begin{array}{l}(0.003) \\
0.019^{* * *} \\
(0.004)\end{array}$ \\
\hline$[-1,2]$ & $\begin{array}{l}0.011^{* * * * *} \\
(0.005)\end{array}$ & $\begin{array}{l}0.015^{* * * *} \\
(0.005)\end{array}$ & $\begin{array}{l}0.024^{* * * *} \\
(0.005)\end{array}$ & $\begin{array}{l}0.029^{* * * *} \\
(0.005)\end{array}$ \\
\hline$[-2,1]$ & $\begin{array}{l}0.013^{* * * * *} \\
(0.005)\end{array}$ & $\begin{array}{l}0.015^{* * * * *} \\
(0.005)\end{array}$ & $\begin{array}{l}0.015^{* * * *} \\
(0.005)\end{array}$ & $\begin{array}{l}0.018^{* * * * *} \\
(0.005)\end{array}$ \\
\hline$[-2,2]$ & $\begin{array}{l}0.016^{\text {***** }} \\
(0.005)\end{array}$ & $\begin{array}{l}0.020^{\text {***** }} \\
(0.005)\end{array}$ & $\begin{array}{l}0.023^{* * * *} \\
(0.005)\end{array}$ & $\begin{array}{l}0.028^{* * * *} \\
(0.005)\end{array}$ \\
\hline$[-2,3]$ & $\begin{array}{l}0.019^{\text {***** }} \\
(0.006)\end{array}$ & $\begin{array}{l}0.024^{* * * *} \\
(0.006)\end{array}$ & $\begin{array}{l}0.029^{* * *} \\
(0.006)\end{array}$ & $\begin{array}{l}0.034^{* * * *} \\
(0.006)\end{array}$ \\
\hline$[-3,2]$ & $\begin{array}{l}0.019^{* * * * *} \\
(0.006)\end{array}$ & $\begin{array}{l}0.022^{* * * * *} \\
(0.006)\end{array}$ & $\begin{array}{l}0.024^{* * * *} \\
(0.006)\end{array}$ & $\begin{array}{l}0.027^{* * * *} \\
(0.006)\end{array}$ \\
\hline$[-3,3]$ & $\begin{array}{l}0.022^{\text {***** }} \\
(0.006)\end{array}$ & $\begin{array}{l}0.027^{* * * *} \\
(0.006)\end{array}$ & $\begin{array}{l}0.029^{* * * *} \\
(0.006)\end{array}$ & $\begin{array}{l}0.033^{* * * * *} \\
(0.006)\end{array}$ \\
\hline
\end{tabular}

Note: Numbers in parentheses are standard errors. ${ }^{* * *}: p<.01 ;{ }^{* *}: p<.05 ;^{*}: p<.1$

${ }^{a}$ MRET_TMV: tradable market value-weighted market return

${ }^{\mathrm{b}}$ MRET_MC: market capitalization-weighted market return

${ }^{\mathrm{c}}$ CSI 800: consists of CSI 300 and CSI 500, aiming to comprehensively reflect the price fluctuations and performance of large-, mid-, and small-cap companies on the Shanghai and Shenzhen securities markets, compiled by the China Securities Index Company, Ltd.

${ }^{\mathrm{d}}$ CSI 300: a capitalization-weighted stock market index designed to replicate the performance of 300 stocks traded on the Shanghai and Shenzhen stock exchanges, compiled by the China Securities Index Company, Ltd. 
Table 8 Cross-sectional analysis of the cumulative abnormal returns (using different market portfolios)

\begin{tabular}{|c|c|c|c|c|c|c|c|c|}
\hline & \multicolumn{2}{|c|}{ MRET_TMV ${ }^{\mathrm{a}}$} & \multicolumn{2}{|c|}{ MRET_MC ${ }^{\mathrm{b}}$} & \multicolumn{2}{|l|}{ CSI $800^{\mathrm{c}}$} & \multicolumn{2}{|l|}{ CSI $300^{\mathrm{d}}$} \\
\hline & $\begin{array}{l}\text { Event } \\
\text { Window } \\
{[-2,2]}\end{array}$ & $\begin{array}{l}\text { Event } \\
\text { Window } \\
{[-3,3]}\end{array}$ & $\begin{array}{l}\text { Event } \\
\text { Window } \\
{[-2,2]}\end{array}$ & $\begin{array}{l}\text { Event } \\
\text { Window } \\
{[-3,3]}\end{array}$ & $\begin{array}{l}\text { Event } \\
\text { Window } \\
{[-2,2]}\end{array}$ & $\begin{array}{l}\text { Event } \\
\text { Window } \\
{[-3,3]}\end{array}$ & $\begin{array}{l}\text { Event } \\
\text { Window } \\
{[-2,2]}\end{array}$ & $\begin{array}{l}\text { Event } \\
\text { Window } \\
{[-3,3]}\end{array}$ \\
\hline Intercept & $\begin{array}{l}0.072^{*} \\
(0.037)\end{array}$ & $\begin{array}{l}0.110^{\text {*** }} \\
(0.049)\end{array}$ & $\begin{array}{l}0.072^{*} \\
(0.037)\end{array}$ & $\begin{array}{l}0.113^{* *} \\
(0.048)\end{array}$ & $\begin{array}{l}0.084^{\text {** }} \\
(0.037)\end{array}$ & $\begin{array}{l}0.119^{* * *} \\
(0.048)\end{array}$ & $\begin{array}{l}0.096^{* *} \\
(0.037)\end{array}$ & $\begin{array}{l}0.127^{* *} \\
(0.049)\end{array}$ \\
\hline Advertising $(A D)$ & $\begin{array}{c}-0.159^{* *} \\
(0.064)\end{array}$ & $\begin{array}{c}-0.215^{* * * *} \\
(0.072)\end{array}$ & $\begin{array}{c}-0.157^{* *} \\
(0.064)\end{array}$ & $\begin{array}{c}-0.215^{* * *} \\
(0.062)\end{array}$ & $\begin{array}{c}-0.159^{* *} \\
(0.064)\end{array}$ & $\begin{array}{c}-0.215^{* * *} \\
(0.072)\end{array}$ & $\begin{array}{c}-0.165^{* *} \\
(0.064)\end{array}$ & $\begin{array}{c}-0.220^{* * *} \\
(0.070)\end{array}$ \\
\hline$R \& D(R D)$ & $\begin{array}{l}0.775^{* *} \\
(0.361)\end{array}$ & $\begin{array}{l}0.663^{* *} \\
(0.317)\end{array}$ & $\begin{array}{l}0.762^{* *} \\
(0.363)\end{array}$ & $\begin{array}{l}0.654^{* * *} \\
(0.318)\end{array}$ & $\begin{array}{l}0.782^{* *} \\
(0.362)\end{array}$ & $\begin{array}{l}0.666^{* * *} \\
(0.317)\end{array}$ & $\begin{array}{l}0.784^{* *} \\
(0.367)\end{array}$ & $\begin{array}{l}0.662^{* *} \\
(0.321)\end{array}$ \\
\hline Global-Expanded (GLB) & $\begin{array}{c}0.040^{\text {**** }} \\
(0.012)\end{array}$ & $\begin{array}{c}0.041^{\text {**** }} \\
(0.016)\end{array}$ & $\begin{array}{c}0.041^{* * * *} \\
(0.013)\end{array}$ & $\begin{array}{l}0.041^{\text {*** }} \\
(0.016)\end{array}$ & $\begin{array}{c}0.040^{* * * *} \\
(0.013)\end{array}$ & $\begin{array}{l}0.040^{\text {*** }} \\
(0.016)\end{array}$ & $\begin{array}{c}0.041^{* * * *} \\
(0.012)\end{array}$ & $\begin{array}{l}0.042^{* *} \\
(0.016)\end{array}$ \\
\hline$G L B \_D V P E D$ & $\begin{array}{c}-0.063^{*} \\
(0.035)\end{array}$ & $\begin{array}{c}-0.075^{* *} \\
(0.029)\end{array}$ & $\begin{array}{c}-0.062^{*} \\
(0.035)\end{array}$ & $\begin{array}{c}-0.075^{* *} \\
(0.029)\end{array}$ & $\begin{array}{c}-0.061^{*} \\
(0.035)\end{array}$ & $\begin{array}{c}-0.072^{* * *} \\
(0.029)\end{array}$ & $\begin{array}{c}-0.064^{*} \\
(0.034)\end{array}$ & $\begin{array}{c}-0.078^{* * *} \\
(0.029)\end{array}$ \\
\hline SIZE & $\begin{array}{c}-0.012^{* * *} \\
(0.004)\end{array}$ & $\begin{array}{c}-0.012^{* *} \\
(0.005)\end{array}$ & $\begin{array}{c}-0.008^{* * *} \\
(0.004)\end{array}$ & $\begin{array}{c}-0.012^{* *} \\
(0.005)\end{array}$ & $\begin{array}{c}-0.009^{* * * *} \\
(0.004)\end{array}$ & $\begin{array}{c}-0.011^{* * *} \\
(0.005)\end{array}$ & $\begin{array}{c}-0.009^{* *} \\
(0.004)\end{array}$ & $\begin{array}{c}-0.012^{* * *} \\
(0.005)\end{array}$ \\
\hline OWNERSHIP (OWNER) & $\begin{array}{c}0.008 \\
(0.012)\end{array}$ & $\begin{array}{c}0.002 \\
(0.013)\end{array}$ & $\begin{array}{c}0.009 \\
(0.012)\end{array}$ & $\begin{array}{c}0.003 \\
(0.013)\end{array}$ & $\begin{array}{c}0.009 \\
(0.012)\end{array}$ & $\begin{array}{c}0.003 \\
(0.014)\end{array}$ & $\begin{array}{c}0.009 \\
(0.012)\end{array}$ & $\begin{array}{c}0.003 \\
(0.013)\end{array}$ \\
\hline$C P F$ & $\begin{array}{c}0.024 \\
(0.016)\end{array}$ & $\begin{array}{l}0.030^{* *} \\
(0.014)\end{array}$ & $\begin{array}{c}0.024 \\
(0.016)\end{array}$ & $\begin{array}{l}0.030^{* * *} \\
(0.014)\end{array}$ & $\begin{array}{c}0.022 \\
(0.016)\end{array}$ & $\begin{array}{l}0.027^{*} \\
(0.014)\end{array}$ & $\begin{array}{c}0.026 \\
(0.016)\end{array}$ & $\begin{array}{l}0.032^{* *} \\
(0.014)\end{array}$ \\
\hline$R O A$ & $\begin{array}{c}0.077 \\
(0.111)\end{array}$ & $\begin{array}{c}0.139 \\
(0.121)\end{array}$ & $\begin{array}{c}0.079 \\
(0.110)\end{array}$ & $\begin{array}{c}0.139 \\
(0.120)\end{array}$ & $\begin{array}{c}0.073 \\
(0.110)\end{array}$ & $\begin{array}{c}0.132 \\
(0.120)\end{array}$ & $\begin{array}{c}0.073 \\
(0.122)\end{array}$ & $\begin{array}{c}0.138 \\
(0.123)\end{array}$ \\
\hline FID & $\begin{array}{c}0.024 \\
(0.016)\end{array}$ & $\begin{array}{l}0.030^{* *} \\
(0.014)\end{array}$ & $\begin{array}{c}0.024 \\
(0.016)\end{array}$ & $\begin{array}{l}0.030^{* *} \\
(0.014)\end{array}$ & $\begin{array}{c}0.022 \\
(0.016)\end{array}$ & $\begin{array}{l}0.027^{*} \\
(0.014)\end{array}$ & $\begin{array}{c}0.026 \\
(0.016)\end{array}$ & $\begin{array}{l}0.032^{* *} \\
(0.014)\end{array}$ \\
\hline SH Dummy & $\begin{array}{c}0.016 \\
(0.011)\end{array}$ & $\begin{array}{c}0.032^{* * * * *} \\
(0.011)\end{array}$ & $\begin{array}{c}0.019 \\
(0.011)\end{array}$ & $\begin{array}{c}0.035^{* * * *} \\
(0.011)\end{array}$ & $\begin{array}{l}0.008 \\
(0.011)\end{array}$ & $\begin{array}{l}0.022^{*} \\
(0.011)\end{array}$ & $\begin{array}{c}0.004 \\
(0.011)\end{array}$ & $\begin{array}{l}0.032^{* *} \\
(0.014)\end{array}$ \\
\hline R-square & 0.183 & 0.264 & 0.186 & 0.266 & 0.170 & 0.236 & 0.177 & 0.272 \\
\hline
\end{tabular}

Note: The dependent variable in the regression is the cumulative abnormal returns at the event window $[-2,2]$ and $[-3,3]$. Numbers in parentheses are heteroscedasticity-consistent standard errors. Sample size $=145$. $^{* * *}, p<0.01,{ }^{* * *}, p<0.05,{ }^{*}, p<0.1$

${ }^{a}$ MRET_TMV: tradable market value-weighted market return

${ }^{\mathrm{b}}$ MRET_MC: market capitalization-weighted market return

${ }^{\mathrm{c}} \mathrm{CSI}$ 800: consists of CSI 300 and CSI 500, aiming to comprehensively reflect the price fluctuations and performance of large-, mid-, and small-cap companies on the Shanghai and Shenzhen securities markets, compiled by the China Securities Index Company, Ltd.

${ }^{\mathrm{d}}$ CSI 300: a capitalization-weighted stock market index designed to replicate the performance of 300 stocks traded on the Shanghai and Shenzhen stock exchanges, compiled by the China Securities Index Company, Ltd.

\section{Appendix 3: Heckman two-stage estimation}

Table 9 Variable measurement and descriptive statistics in the Heckman two-stage estimation

\begin{tabular}{|c|c|c|c|c|}
\hline Variable & Variable Measurement & Data Source & Mean & $\begin{array}{l}\text { Standard } \\
\text { Deviation }\end{array}$ \\
\hline Return On Assets (ROA) & The net income over total assets in the year prior to the focal event. & RESSET & 0.047 & 0.839 \\
\hline SH Index dummy & Coded as 1 if the firm is listed on the Shanghai Exchange Market, and 0 otherwise. & RESSET & 0.535 & 0.498 \\
\hline $\begin{array}{l}\text { Foreign investor } \\
\text { share-holding }\end{array}$ & $\begin{array}{l}\text { Coded as } 1 \text { if the firm has either an H-share or a B-share, and } 0 \text { otherwise. For Chinese firms with } \\
\text { an } \mathrm{H} \text {-share, they are also listed on the Hong Kong Exchange Market. For companies with a } \\
\text { B-share, foreign investors can buy the stock directly via foreign currencies. }\end{array}$ & RESSET & 0.088 & 0.283 \\
\hline $\begin{array}{l}\text { Comprehensive } \\
\text { CSR_Report }\end{array}$ & $\begin{array}{l}\text { Coded as } 1 \text { if the CSR information compiled by the company follows the G3 standards and is } \\
\text { comprehensive in the six aspects (shareholder, bondholder, employee, customer, community, } \\
\text { and environment). }\end{array}$ & CCSR & 0.199 & 0.399 \\
\hline Total donation & The total amount of donations in the year prior to the focal events (in $10,000 \mathrm{RMB}$ ). & CCSR & 188.740 & 1290.070 \\
\hline
\end{tabular}


Table 9 (continued)

\begin{tabular}{|c|c|c|c|c|}
\hline Variable & Variable Measurement & Data Source & Mean & $\begin{array}{l}\text { Standard } \\
\text { Deviation }\end{array}$ \\
\hline CSR Industry Average & $\begin{array}{l}\text { The average CSR in each industry is calculated based on the composite score derived by } \\
\text { summing up each firm's score on important CSR dimensions including social, } \\
\text { environment, and governance performance in the year prior to the focal event. }\end{array}$ & CCSR & 0.022 & 2.567 \\
\hline Industry Competition & $\begin{array}{l}\text { The Herfindahl index is calculated at the industry level for each firm, using the sales revenue and } \\
\text { market share of each firm. A higher value indicates higher competition in the respective industry. }\end{array}$ & RESSET & 0.863 & 0.142 \\
\hline Institution Development & $\begin{array}{l}\text { This is a composite annual index of "marketization" to indicate institutional development } \\
\text { at the provincial level (Zhou et al. 2017). }\end{array}$ & NERI & 6.466 & 1.317 \\
\hline Firm age & This is the time span between the year of the firm's establishment and the focal event year. & RESSET & 12.195 & 4.383 \\
\hline $\begin{array}{l}\text { Top_Mngmt } \\
\text { shareholding }\end{array}$ & The stock share held by senior executives divided by the total share. & RESSET & 0.011 & 0.067 \\
\hline
\end{tabular}

RESSET: a financial database for Chinese stock markets compiled by the Beijing Gildata Resset Data Tech Co., Ltd.

CCSR: Chinese Corporate Social Responsibility Database compiled by a financial service company - Efindata

NERI Index: an Index representing the economic, political and legal development in China compiled by the National Economic Research Institute at Renmin University, China

Table 10 Heckman two-stage estimation results

\begin{tabular}{|c|c|c|c|c|c|}
\hline & \multirow[t]{2}{*}{ First-Stage Estimation } & \multicolumn{4}{|c|}{ Second-Stage Estimation } \\
\hline & & Window $[-2,2]$ & Window $[-2,3]$ & Window $[-3,2]$ & Window $[-3,3]$ \\
\hline Intercept & $\begin{array}{l}-9.808^{* * *} \\
(1.206)\end{array}$ & $\begin{array}{l}0.194^{* *} \\
(0.087)\end{array}$ & $\begin{array}{l}0.280^{\text {**** }} \\
(0.087)\end{array}$ & $\begin{array}{l}0.251^{* * *} \\
(0.114)\end{array}$ & $\begin{array}{l}0.337^{* * * *} \\
(0.119)\end{array}$ \\
\hline Advertising $(A D)$ & $\begin{array}{l}0.075 \\
(0.063)\end{array}$ & $\begin{array}{l}-0.153^{* *} \\
(0.065)\end{array}$ & $\begin{array}{l}-0.188^{* * *} \\
(0.068)\end{array}$ & $\begin{array}{l}-0.188^{* *} \\
(0.073)\end{array}$ & $\begin{array}{l}-0.222^{\text {**** }} \\
(0.071)\end{array}$ \\
\hline$R \& D(R D)$ & $\begin{array}{l}13.949 \\
(9.621)\end{array}$ & $\begin{array}{l}0.654^{* *} \\
(0.332)\end{array}$ & $\begin{array}{l}0.692^{* *} \\
(0.284)\end{array}$ & $\begin{array}{l}0.613^{* *} \\
(0.315)\end{array}$ & $\begin{array}{l}0.650^{* *} \\
(0.301)\end{array}$ \\
\hline$G L B$ & $\begin{array}{l}0.045 \\
(0.800)\end{array}$ & $\begin{array}{l}0.044^{* * *} \\
(0.013)\end{array}$ & $\begin{array}{l}0.043^{\text {**** }} \\
(0.013)\end{array}$ & $\begin{array}{l}0.039^{* * *} \\
(0.014)\end{array}$ & $\begin{array}{l}0.038^{* *} \\
(0.015)\end{array}$ \\
\hline$G L B \_D V P E D$ & $\begin{array}{l}-0.626 \\
(1.073)\end{array}$ & $\begin{array}{l}-0.057^{*} \\
(0.033)\end{array}$ & $\begin{array}{l}-0.068^{* * *} \\
(0.035)\end{array}$ & $\begin{array}{l}-0.048^{*} \\
(0.027)\end{array}$ & $\begin{array}{l}-0.059^{* *} \\
(0.029)\end{array}$ \\
\hline SIZE & $\begin{array}{l}0.397^{\text {*** }} \\
(0.051)\end{array}$ & $\begin{array}{l}-0.007^{* *} \\
(0.003)\end{array}$ & $\begin{array}{l}-0.011^{* * * *} \\
(0.003)\end{array}$ & $\begin{array}{l}-0.009^{* *} \\
(0.004)\end{array}$ & $\begin{array}{l}-0.012^{* * *} \\
(0.005)\end{array}$ \\
\hline OWNERSHIP (OWNER) & $\begin{array}{l}-0.573^{* * *} \\
(0.242)\end{array}$ & $\begin{array}{l}0.006 \\
(0.012)\end{array}$ & $\begin{array}{l}-0.001 \\
(0.012)\end{array}$ & $\begin{array}{l}0.007 \\
(0.012)\end{array}$ & $\begin{array}{l}-0.0001 \\
(0.013)\end{array}$ \\
\hline$C P F$ & $\begin{array}{l}0.144 \\
(0.128)\end{array}$ & $\begin{array}{l}0.039^{* * *} \\
(0.011)\end{array}$ & $\begin{array}{l}0.055^{\text {**** }} \\
(0.011)\end{array}$ & $\begin{array}{l}0.043^{* * *} \\
(0.014)\end{array}$ & $\begin{array}{l}0.058^{* * *} \\
(0.013)\end{array}$ \\
\hline$R O A$ & $\begin{array}{l}0.037 \\
(0.043)\end{array}$ & $\begin{array}{l}0.080 \\
(0.111)\end{array}$ & $\begin{array}{l}0.106 \\
(0.129)\end{array}$ & $\begin{array}{l}0.095 \\
(0.105)\end{array}$ & $\begin{array}{l}0.122 \\
(0.121)\end{array}$ \\
\hline SH Index dummy & $\begin{array}{l}-0.285^{* * *} \\
(0.106)\end{array}$ & $\begin{array}{l}0.021^{*} \\
(0.012)\end{array}$ & $\begin{array}{l}0.033^{\text {**** }} \\
(0.012)\end{array}$ & $\begin{array}{l}0.020^{*} \\
(0.015)\end{array}$ & $\begin{array}{l}0.032^{* * * *} \\
(0.013)\end{array}$ \\
\hline Foreign investor share-holding & $\begin{array}{l}-0.260 \\
(0.190)\end{array}$ & $\begin{array}{l}0.015 \\
(0.015)\end{array}$ & $\begin{array}{l}0.014 \\
(0.016)\end{array}$ & $\begin{array}{l}0.020 \\
(0.015)\end{array}$ & $\begin{array}{l}0.019 \\
(0.014)\end{array}$ \\
\hline $\begin{array}{l}\text { Comprehensive } \\
\text { CSR_Report } \\
\text { Total donation in } 2008\end{array}$ & $\begin{array}{l}1.404^{\text {**** }} \\
(0.108) \\
-0.001 \\
(0.003)\end{array}$ & & & & \\
\hline CSR Industry Average & $\begin{array}{l}0.038^{*} \\
(0.022)\end{array}$ & & & & \\
\hline Industry Competition & $\begin{array}{l}-0.375 \\
(0.413)\end{array}$ & & & & \\
\hline Institution Development & $\begin{array}{l}0.059 \\
(0.042)\end{array}$ & & & & \\
\hline Firm age & $-0.033^{* * *}$ & & & & \\
\hline
\end{tabular}


Table 10 (continued)

\begin{tabular}{|c|c|c|c|c|c|}
\hline & \multirow[t]{2}{*}{ First-Stage Estimation } & \multicolumn{4}{|c|}{ Second-Stage Estimation } \\
\hline & & Window $[-2,2]$ & Window $[-2,3]$ & Window $[-3,2]$ & Window $[-3,3]$ \\
\hline Top_Mngmt shareholding & $\begin{array}{l}(0.011) \\
0.363 \\
(0.798)\end{array}$ & & & & \\
\hline Inverse Mills' Ratio & & $\begin{array}{l}-0.051 \\
(0.048)\end{array}$ & $\begin{array}{l}-0.049 \\
(0.049)\end{array}$ & $\begin{array}{l}-0.072 \\
(0.050)\end{array}$ & $\begin{array}{l}-0.069 \\
(0.051)\end{array}$ \\
\hline Sample Size & $N=1509$ & $\mathrm{~N}=145$ & $\mathrm{~N}=145$ & $\mathrm{~N}=145$ & $\mathrm{~N}=145$ \\
\hline$R$-Squared & 0.345 & 0.188 & 0.274 & 0.197 & 0.284 \\
\hline
\end{tabular}

${ }^{* * *}: p<0.01,{ }^{* *}: p<0.05,{ }^{*}: p<0.1$. Numbers in parentheses are heteroscedasticity-consistent standard errors

\section{Appendix 4: Empirical analysis using the 9-year China sample}

Table 11 Abnormal returns to the SRI index announcements from 2009 to 2017

\begin{tabular}{lllllll}
\hline & CAR $[0]$ & CAR $[0,1]$ & CAR $[0,2]$ & CAR $[-1,1]$ & CAR $[-2,2]$ & CAR[-3,3] \\
\hline 9-Year China Sample & $0.007^{* * *}$ & $0.007^{* * *}$ & $0.010^{* * * *}$ & $0.011^{* * *}$ & $0.014^{* * *}$ & $0.012^{* * *}$ \\
\hline
\end{tabular}

${ }^{* * * *}: p<0.01 ;{ }^{* *}: p<0.05 ;{ }^{*}: p<0.1$. Number of firms in the 9-Year China sample $N=259$

Table 12 Cross-sectional analysis of cumulative abnormal returns (using the 9-year China sample from 2009 to 2017)

\begin{tabular}{|c|c|c|c|c|}
\hline Variable & Event Window $[-2,2])$ & Event Window $[-3,2]$ & Event Window $[-2,3]$ & Event Window $[-3,3]$ \\
\hline Intercept & $\begin{array}{l}5.568 \\
(3.490)\end{array}$ & $\begin{array}{l}9.693^{* * * *} \\
(3.659)\end{array}$ & $\begin{array}{l}6.930^{* * * *} \\
(3.952)\end{array}$ & $\begin{array}{l}11.054^{* * * * *} \\
(4.071)\end{array}$ \\
\hline Advertising $(A D)$ & $\begin{array}{l}-0.001 \\
(0.001)\end{array}$ & $\begin{array}{l}-0.005^{\text {****** }} \\
(0.001)\end{array}$ & $\begin{array}{l}-0.001 \\
(0.001)\end{array}$ & $\begin{array}{l}-0.005^{\text {****** }} \\
(0.001)\end{array}$ \\
\hline$R \& D$ Expenditure ( $R D)$ & $\begin{array}{l}0.657^{* * *} \\
(0.319)\end{array}$ & $\begin{array}{l}0.604^{* *} \\
(0.304)\end{array}$ & $\begin{array}{l}0.781^{* * * * *} \\
(0.277)\end{array}$ & $\begin{array}{l}0.727^{\text {*** }} \\
(0.267)\end{array}$ \\
\hline Global-Expanded (GLB) & $\begin{array}{l}0.044^{\text {**** }} \\
(0.011)\end{array}$ & $\begin{array}{l}0.040^{* * * *} \\
(0.012)\end{array}$ & $\begin{array}{l}0.044^{* * * *} \\
(0.013)\end{array}$ & $\begin{array}{l}0.039^{* * *} \\
(0.015)\end{array}$ \\
\hline$G L B \_D V P E D$ & $\begin{array}{l}-0.073^{* * *} \\
(0.021)\end{array}$ & $\begin{array}{l}-0.066^{* * * *} \\
(0.019)\end{array}$ & $\begin{array}{l}-0.086^{* * * *} \\
(0.022)\end{array}$ & $\begin{array}{l}-0.078^{* * * *} \\
(0.022)\end{array}$ \\
\hline SIZE & $\begin{array}{l}-0.003 \\
(0.003)\end{array}$ & $\begin{array}{l}-0.001 \\
(0.003)\end{array}$ & $\begin{array}{l}-0.004 \\
(0.003)\end{array}$ & $\begin{array}{l}-0.002 \\
(0.003)\end{array}$ \\
\hline OWNERSHIP (OWNER) & $\begin{array}{l}0.007 \\
(0.013)\end{array}$ & $\begin{array}{l}-0.005 \\
(0.013)\end{array}$ & $\begin{array}{l}0.016 \\
(0.012)\end{array}$ & $\begin{array}{l}-0.006 \\
(0.013)\end{array}$ \\
\hline Consumer-Product Firms (CPF) & $\begin{array}{l}0.022^{*} \\
(0.013)\end{array}$ & $\begin{array}{l}0.022 \\
(0.014)\end{array}$ & $\begin{array}{l}0.029^{* * *} \\
(0.014)\end{array}$ & $\begin{array}{l}0.030^{* * *} \\
(0.015)\end{array}$ \\
\hline$R O A$ & $\begin{array}{l}-0.048 \\
(0.100)\end{array}$ & $\begin{array}{l}-0.013 \\
(0.098)\end{array}$ & $\begin{array}{l}-0.039 \\
(0.124)\end{array}$ & $\begin{array}{l}-0.004 \\
(0.121)\end{array}$ \\
\hline Foreign Investor Holding (FID) & $\begin{array}{l}0.020^{*} \\
(0.011)\end{array}$ & $\begin{array}{l}0.022^{* *} \\
(0.011)\end{array}$ & $\begin{array}{l}0.016 \\
(0.012)\end{array}$ & $\begin{array}{l}0.018 \\
(0.011)\end{array}$ \\
\hline Shanghai & $\begin{array}{l}0.015 \\
(0.011)\end{array}$ & $\begin{array}{l}0.012 \\
(0.011)\end{array}$ & $\begin{array}{l}0.027^{* * *} \\
(0.011)\end{array}$ & $\begin{array}{l}0.024^{* *} \\
(0.011)\end{array}$ \\
\hline Year_trend & $\begin{array}{l}-0.003^{*} \\
(0.002)\end{array}$ & $\begin{array}{l}-0.005^{* *} \\
(0.002)\end{array}$ & $\begin{array}{l}-0.003^{*} \\
(0.002)\end{array}$ & $\begin{array}{l}-0.005^{* * *} \\
(0.002)\end{array}$ \\
\hline R-squared & 0.097 & 0.101 & 0.126 & 0.129 \\
\hline
\end{tabular}

${ }^{* * * *}: p<0.01 ;{ }^{* *}: p<0.05 ;$ and ${ }^{*}: p<0.1$. Numbers in parentheses are heteroscedasticity-consistent standard errors. Sample size $\mathrm{N}=259$ 
Open Access This article is distributed under the terms of the Creative Commons Attribution 4.0 International License (http://creativecommons.org/ licenses/by/4.0/), which permits unrestricted use, distribution, and reproduction in any medium, provided you give appropriate credit to the original author(s) and the source, provide a link to the Creative Commons license, and indicate if changes were made.

\section{References}

Arya, B., \& Zhang, G. (2009). Institutional reforms and investor reactions to CSR announcements: Evidence from an emerging economy. Journal of Management Studies, 46(7), 1089-1112.

Bhattacharya, C. B., \& Sen, S. (2004). Doing better at doing good: When, why, and how consumers respond to corporate social initiatives. California Management Review, 47, 9-24.

Boston Consulting Group (BCG) (2009). The 2009 BCG 100 new global challengers: How companies from rapidly developing economies are contending global leadership.

Burgess, S. M., \& Steenkamp, J. E. M. (2006). Marketing renaissance: How research in emerging markets advances marketing science and practice. International Journal of Research in Marketing, 23(4), 337-356.

Chen, Y., Liu, Y., \& Zhang, J. (2012). When do third-party product reviews affect firm value and what can firms do? The case of media critics and professional movie reviews. Journal of Marketing, 76(2), 116-134.

Chen, Y. C., Hung, M., \& Wang, Y. (2017). The effect of mandatory CSR disclosure on firm profitability and social externalities: Evidence from China. Journal of Accounting and Economics, 65(1), 169-190.

Clacher, I., \& Hagendorff, J. (2012). Do announcements about corporate social responsibility create or destroy shareholder wealth? Evidence from the UK. Journal of Business Ethics, 106, 253-266.

Collins, C. J., \& Han, J. (2004). Exploring applicant pool quantity and quality: The effects of early recruitment practice strategies, corporate advertising, and firm reputation. Personnel Psychology, 57, 685717.

Connelly, B. L., Certo, S. T., Ireland, R. D., \& Reutzel, C. R. (2011). Signaling theory: A review and assessment. Journal of Management, 37(1), 39-67.

CSM (Centre for Social Markets) (2001). Corporate social responsibility: Perceptions of Indian business, a report by CSM, Calcutta, India. [http://csmworld.org/wp-content/uploads/2009/03/social_respons. pdf].

Curran, M. M., \& Moran, D. (2007). Impact of the FTSE4Good index on firm price: An event study. Journal of Environmental Management, 82(3), 529-537.

Ding, Y., Stolowy, H., \& Tenenhaus, M. (2007). R\&D productivity: An exploratory international study. Review of Accounting and Finance, 6(1), 86-101.

Economist (2008 Sept. 18). The new champion, http://www.economist. com/node/12080711.

Ghoul, S. E., Guedhami, O., Kwok, C. C. Y., \& Mishra, D. (2011). Does corporate social responsibility affect the cost of capital? Journal of Banking \& Finance, 35(9), 2388-2406.

Graves, S. B., \& Waddock, S. A. (1994). Institutional owners and corporate social performance. The Academy of Management Journal, 37(4), 1034-1046.

Gulati, R., \& Higgins, M. (2003). Which ties matter when? The contingent effects of interorganizational partnership on IPO success. Strategic Management Journal, 24, 127-144.

Guo, H., \& Fung, H. (2011). The growth enterprise board IPOs: Characteristics, volatility and the initial-day performance. China \& World Economy, 19, 106-121.
Heider, F. (1958). The psychology of interpersonal relations. New York: Wiley.

Higgins, M., \& Gulati, R. (2006). Stacking the deck: Effects of top management background on investor decisions. Strategic Management Journal, 27, 1-25.

Huang, F., \& Li, C. (2012). Comparisons of PE and PB between SDB and Vanke A. International Journal of Business and Management, 5(5), 124-129.

Hull, C. E., \& Rothenberg, S. (2008). Firm performance: The interactions of corporate social performance with innovation and industry differentiation. Strategic Management Journal, 29(7), 781-789.

Ince, O. S., \& Porter, R. B. (2006). Individual equity return data from Thomson Datastream: Handle with care! The Journal of Financial Research, 29, 463-479.

Johnson, R. A., \& Greening, D. W. (1999). The effects of corporate governance and institutional ownership types on corporate social performance. The Academy of Management Journal, 42(5), 564 576.

Jones, E. E., Kannouse, D. E., Kelley, H. H., Nisbett, R. E., Valins, S., \& Weiner, B. (Eds.). (1972). Attribution: Perceiving the Causes of Behavior. Morristown: General Learning Press.

Kalaignanam, K., Shankar, V., \& Varadarajan, R. (2007). Asymmetric new product development alliances: Win-win or win-lose partnerships. Management Science, 53(3), 357-374.

Kelley, H. H. (1967). "Attribution Theory in Social Psychology," in D. Levine (Ed.), Nebraska symposium on motivation. Lincoln: University of Nebraska Press.

Khan, A., Muttakin, M. B., \& Siddiqui, J. (2013). Corporate governance and corporate social responsibility disclosures: Evidence from an emerging economy. Journal of Business Ethics, 114(2), 207-223.

Kirmani, A., \& Rao, A. R. (2000). No pain, no gain: A critical review of the literature on signaling unobservable product quality. Journal of Marketing, 64(2), 66-79.

Koh, P., \& Reeb, D. M. (2015). Missing R\&D. Journal of Accounting and Economics, 60(1), 73-94.

Koh, P. S., Qian, G., \& Wang, H. (2014). Firm litigation risk and the insurance value of corporate social performance. Strategic Management Journal, 35, 1464-1482.

Kothari, S. P., \& Warner, J. B. (2007). Econometrics of event studies. In B. E. Eckbo (Ed.), Handbook of Corporate Finance, North Holland Elsevier (pp. 3--36).

Krishna, C. G. (1992). Corporate social responsibility in India. New Delhi: Mittal Publications.

Lemmon, M., \& Lins, K. (2003). Ownership structure, corporate governance, and firm value: Evidence from the east Asian financial crisis. Journal of Finance, 58, 1445-1468.

Lenz, I., Wetzel, H. A., \& Hammerschmidt, M. (2017). Can doing good lead to doing poorly? Firm value implications of CSR in the face of CSI. Journal of the Academy of Marketing Science, 45(5), 677-697.

Li, W., \& Zhang, R. (2010). Corporate social responsibility, ownership structure, and political interference: Evidence from China. Journal of Business Ethics, 96(4), 631-645.

Lourenço, I. C., \& Branco, M. C. (2013). Determinants of corporate sustainability performance in emerging markets: The Brazilian case. Journal of Cleaner Production, 57, 134-141.

Luo, X., \& Bhattacharya, C. B. (2006). Corporate social responsibility, customer satisfaction, and market value. Journal of Marketing, 70, $1-18$.

Luo, X., \& Bhattacharya, C. B. (2009). The debate over doing good: Corporate social performance, strategic marketing levers, and firmidiosyncratic risk. Journal of Marketing, 73, 198-213.

MacKinlay, C. A. (1997). Event studies in economics and finance. Journal of Economic Literature, 35(1), 13-39.

McGuinness, P., Vieito, J. P., \& Wang, M. (2017). The role of board gender and foreign ownership in the CSR performance of Chinese listed firms. Journal of Corporate Finance, 42, 75-99. 
McKinsey Quarterly. (2015). Why emerging-market companies acquire abroad (Vol. 55, pp. 7-9).

McWilliams, A., \& Siegel, D. (2000). Corporate social responsibility and financial performance: Correlation or misspecification? Strategic Management Journal, 21(5), 603-609.

Menz, K. M. (2010). Corporate social responsibility: Is it rewarded by the corporate bond market? A critical note. Journal of Business Ethics, 96(1), 117-134.

Mishra, S., \& Modi, S. B. (2016). Corporate social responsibility and shareholder wealth: The role of marketing capability. Journal of Marketing, 80(1), 26-46.

Mishra, S., \& Suar, D. A. (2010). Does corporate social responsibility influence firm performance of Indian companies? Journal of Business Ethics, 95(4), 571-601.

Mizik, N., \& Jacobson, R. (2003). Trading off between value creation and value appropriation: The financial implications of shift in strategic emphasis. Journal of Marketing, 67(1), 63-76.

Nakai, M., Yamaguchi, K., \& Takeuchi, K. (2013). Sustainability membership and stock price: An empirical study using the MorningstarSRI index. Applied Financial Economics, 23, 71-77.

Oberndorfer, U., Schmidt, P., Wagner, M., \& Ziegler, A. (2013). Does the stock market value the inclusion in a sustainability stock index? An event study analysis for German firms. Journal of Environmental Economics and Management, 66, 497-509.

Peloza, J., \& Shang, J. (2011). How can corporate social responsibility activities create value for stakeholders? A systematic review. Journal of the Academy of Marketing Science, 39(1), 117-135.

Porter, M. (1974). Consumer behavior, retailer power and market performance in consumer goods industries. The Review of Economics and Statistics, 56(4), 419-436.

Ptok, A., Jindal, R., \& Reinartz, W. (2018). Selling, general, and administrative expense (SGA)-based metrics in marketing: Conceptual and measurement challenges. Journal of the Academy of Marketing Science, 46(6), 987-1011.

Ramchander, S., Schwebach, R. G., \& Staking, K. (2012). The informational relevance of corporate social responsibility: Evidence from DS400 index reconstitutions. Strategic Management Journal, 33, 303-314.

Russo, A., \& Mariani, M. (2013). Drawbacks of a delisting from a sustainability index: An empirical analysis. International Journal of Business Administration, 4(6), 29-40.

Sauer, D. (1997). The impact of social-responsibility screens on investment performance: Evidence from the Domini 400 social index and Domini equity fund. Review of Financial Economics, 6(2), 137149

Servaes, H., \& Tamayo, A. (2013). The impact of corporate social responsibility on firm value: The role of customer awareness. Management Science, 59(5), 1045-1061.

Settle, R. B., \& Golden, L. L. (1974). Attribution theory and advertiser credibility. Journal of Marketing Research, 11, 181-185.
Sonnenberg, D., \& Hamann, R. (2006). The JSE socially responsible investment index and the state of sustainability reporting in South Africa. Development Southern Africa, 23(2), 305-320.

Sood, A., \& Tellis, G. J. (2009). Do innovations really payoff? Total stock market returns to innovation. Marketing Science, 28(3), 442-456.

Sparkes, R. (2001). Ethical investment: Whose ethics, which investment. Business Ethics: A European Review, 10(3), 194-205.

Spence, M. (1973). Job market signaling. The Quarterly Journal of Economics, 87(3), 355-374.

Statman, M. (2000). Socially responsible mutual funds. Financial Analysts Journal, 56, 30-39.

Su, W., Peng, M., Tan, W., \& Cheung, Y. L. (2016). The signaling effect of corporate social responsibility in emerging economies. Journal of Business Ethics, 134, 479-491.

Swaminathan, V., \& Moorman, C. (2009). Marketing alliances, firm networks, and firm value creation. Journal of Marketing, 72, 52-69.

The African Executive (December 13, 2012). Emerging African markets: MNCs must partner with NGOs.

Vidaver-Cohen, D., \& Altma, B. W. (2000). Corporate citizenship in the new millennium: Foundation for an architecture of excellence. Business and Society Review, 105(1), 145-168.

Waddock, S. A., \& Graves, S. B. (1997). The corporate social responsibility-financial performance link. Strategic Management Journal, 18(4), 303-319.

Wang, K. T., \& Li, D. (2016). Market reactions to the first-time disclosure of corporate social responsibility reports: Evidence from China. Journal of Business Ethics, 138, 661-682.

Wang, H., Choi, H., \& Li, J. T. (2008). Too little or too much? Untangling the relationship between philanthopy and firm financial performance. Organization Science, 19, 143-159.

Webb, D., \& Mohr, L. (1998). A typology of consumer responses to cause-related marketing: From skeptics to socially concerned. Journal of Public Policy and Marketing, 17(2), 226-239.

Williams, M. J. (1986). How to cash in on do-good pitches. Fortune $113(12), 71-80$.

Zhang, R., Zhu, J., Yue, H., \& Zhu, C. (2010). Corporate philanthropic giving, advertising intensity, and industry competition level. Journal of Business Ethics, 94(1), 39-52.

Zhou, C. X., Wang, Q., \& Xie, J. H. (2016). Failure to complete crossborder M\&as: "To" vs. "from" emerging markets. Journal of International Business Studies, 47(9), 1077-1105.

Zhou, K. Z., Gao, G., \& Zhao, H. (2017). State ownership and firm innovation in China: An integrated view of institutional and efficiency logics. Administrative Science Quarterly, 62(2), 375-404.

Publisher's note Springer Nature remains neutral with regard to jurisdictional claims in published maps and institutional affiliations. 